\title{
A new correlation of Triassic-Jurassic boundary successions in NW Europe, Nevada and Peru, and the Central Atlantic Magmatic Province: A time-line for the end-Triassic mass extinction
}

\author{
Sofie Lindström ${ }^{\mathrm{a}, *}$, Bas van de Schootbrugge ${ }^{\mathrm{b}}$, Katrine H. Hansen ${ }^{\mathrm{c}}$, Gunver K. Pedersen ${ }^{\mathrm{a}}$, Peter Alsen ${ }^{\mathrm{a}}$, \\ Nicolas Thibault ${ }^{c}$, Karen Dybkjær ${ }^{\mathrm{a}}$, Christian J. Bjerrum ${ }^{\mathrm{c}}$, Lars Henrik Nielsen ${ }^{\mathrm{a}}$ \\ a GEUS Geological Survey of Denmark and Greenland, Øster Voldgade 10, DK-1350 Copenhagen K, Denmark \\ ${ }^{\mathrm{b}}$ Institute of Earth Sciences, Utrecht University, Budapestlaan 4, 3584 CS Utrecht, The Netherlands \\ c Department of Geosciences and Natural Resource Management, University of Copenhagen, Øster Voldgade 10, DK-1350 Copenhagen K, Denmark
}

\section{A R T I C L E I N F O}

\section{Article history:}

Received 22 July 2016

Received in revised form 16 December 2016

Accepted 18 December 2016

Available online 21 December 2016

\section{Keywords:}

Ammonites

Palynology

Carbon isotopes

Geochronology

Rhaetian

Hettangian

\begin{abstract}
A B S T R A C T
Understanding the end-Triassic mass extinction event (201.36 Ma) requires a clear insight into the stratigraphy of boundary sections, which allows for long-distance correlations and correct distinction of the sequence of events. However, even after the ratification of a Global Stratotype Section and Point, global correlations of TJB successions are hampered by the fact that many of the traditionally used fossil groups were severely affected by the crisis. Here, a new correlation of key TJB successions in Europe, U.S.A. and Peru, based on a combination of biotic (palynology and ammonites), geochemical $\left(\delta^{13} \mathrm{C}_{\mathrm{org}}\right)$ and radiometric $(\mathrm{U} / \mathrm{Pb}$ ages) constraints, is presented. This new correlation has an impact on the causality and temporal development during the end-Triassic event. It challenges the hitherto used standard correlation, which has formed the basis for a hypothesis that the extinction was caused by more or less instantaneous release of large quantities of light carbon (methane) to the atmosphere, with catastrophic global warming as a consequence. The new correlation instead advocates a more prolonged scenario with a series of feedback mechanisms, as it indicates that the bulk of the hitherto dated, high-titanium, quartz normalized volcanism of the Central Atlantic Magmatic Province (CAMP) preceded or was contemporaneous to the onset of the mass extinction. In addition, the maximum phase of the mass extinction, which affected both the terrestrial and marine ecosystems, was associated with a major regression and repeated, enhanced earthquake activity in Europe. A subsequent transgression resulted in the formation of hiati or condensed successions in many areas in Europe. Later phases of volcanic activity of the CAMP, producing low titanium, quartz normalized and high-iron, quartz normalized basaltic rocks, continued close to the first occurrence of Jurassic ammonites and the defined TJB. During this time the terrestrial ecosystem had begun to recover, but the marine ecosystem remained disturbed.
\end{abstract}

(c) 2016 Elsevier B.V. All rights reserved.

\section{Introduction}

The Triassic-Jurassic boundary (TJB, 201.36 Ma; Wotzlaw et al., 2014) is associated with one of the most severe biotic crises during the Phanerozoic, the end-Triassic mass extinction (Raup and Sepkoski, 1982; Stanley, 2007), which caused floral and faunal turnovers on land (McElwain et al., 1999, 2007; Olsen et al., 2002; Whiteside et al., 2007; van de Schootbrugge et al., 2009), and major extinctions in the marine realm (Hallam and Wignall, 1999; Hautmann, 2004; van de Schootbrugge et al., 2007). Based on the ecological severity, the event was ranked the third most severe crisis of the Phanerozoic (McGhee et al., 2004, 2013). Taxonomic severity during this event has been

\footnotetext{
* Corresponding author.

E-mail address: sli@geus.dk (S. Lindström).
}

estimated to 40-73\% loss in diversity (Sepkoski, 1996; Alroy, 2010). The biotic crisis severely affected many of the fossil groups traditionally used as stratigraphic markers. In addition, tectonism and sea-level changes related to the initial break-up of Pangea resulted in breaks in the sedimentary record in many marine areas. These factors and other events related to the end-Triassic biotic crisis complicated and delayed the definition of the base of the Jurassic for decades. However, in April 2010 a Global Stratotype Section and Point (GSSP) was finally ratified, and later inaugurated in 2011 by the International Commission on Stratigraphy (Morton, 2012; Hillebrandt et al., 2013).

The GSSP for the base of the Jurassic, Kuhjoch, is located in the Karwendel Mountains in the Northern Calcareous Alps, Austria (Fig. 1). The first occurrence of the hitherto oldest Jurassic ammonoid Psiloceras spelae tirolicum Hillebrandt and Krystyn, 2009 was chosen as a marker for the base of the Jurassic (Hillebrandt et al., 2013) (Fig. 2). 

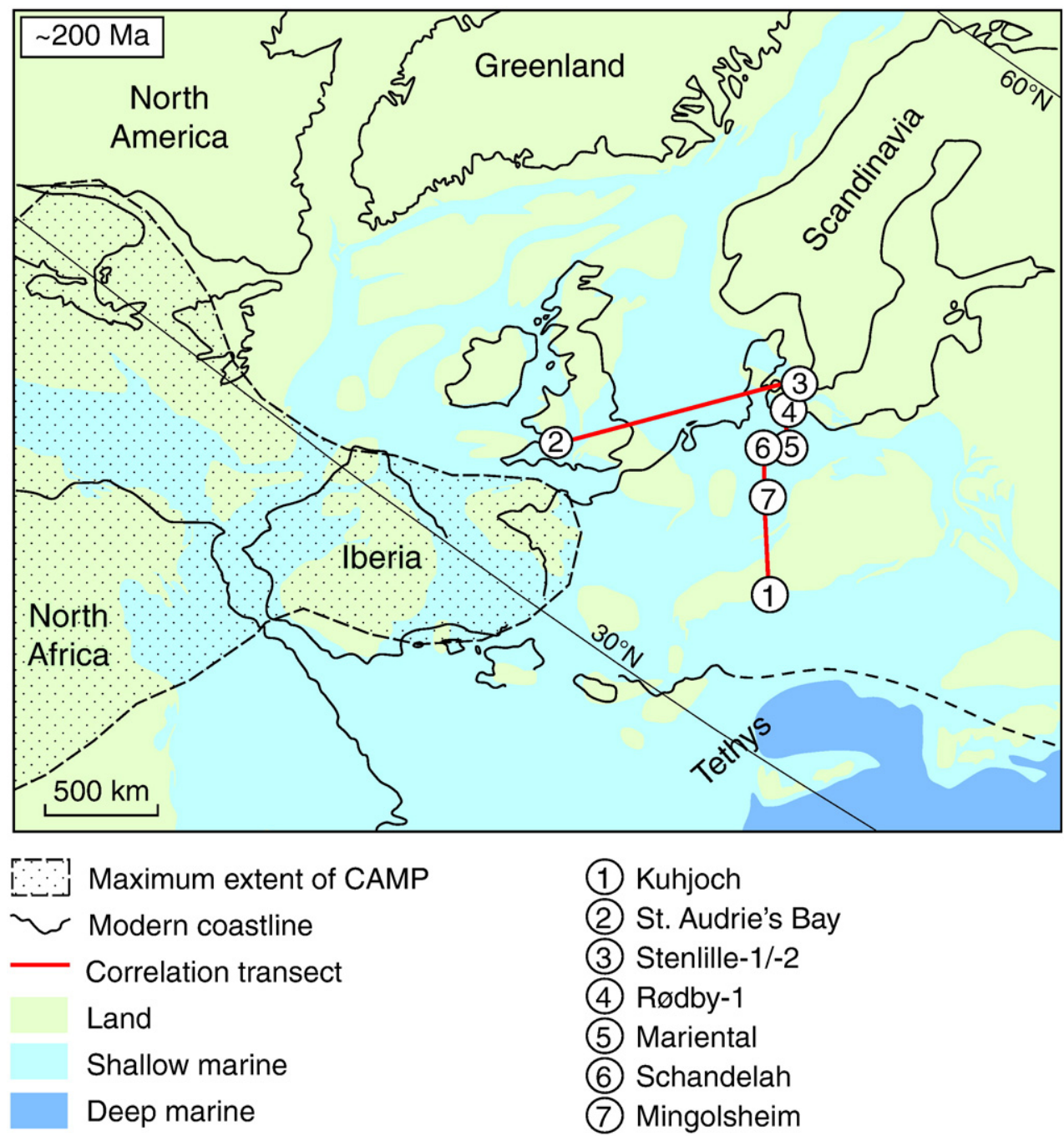

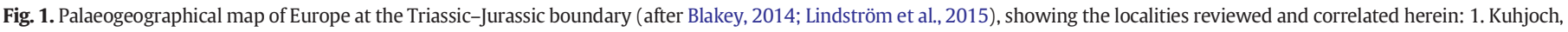

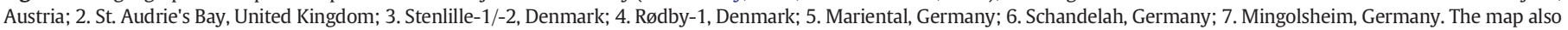
shows the northernmost extension of the CAMP volcanism. Red line = transect shown in Figs. 12-13.

At the time of the voting for Kuhjoch as GSSP for the base of the Jurassic, the section was believed to have a more or less continuous sedimentary record. However, later studies have revealed gaps in the sedimentary record of both the Kuhjoch East and the Kuhjoch West sections, due to local faults (Bonis et al., 2009; Hillebrandt et al., 2013).

Apart from the comprehensive description of the GSSP at Kuhjoch presented in Hillebrandt et al. (2013), several papers have dealt with the macropalaeontology (Hillebrandt and Krystyn, 2009), palynology (Bonis et al., 2009), organic C-isotope stratigraphy (Ruhl et al., 2009, 2011) and geochemistry (Tanner et al., 2016), of the Kuhjoch section. Several studies have focused on other TJB successions located within the same basin, the Eiberg Basin, providing additional important information concerning C-isotopes (Ruhl and Kürschner, 2011; Mette et al., 2012), micropalaeontology (Clémence et al., 2010b), geochemistry and mineralogy (Pálfy and Zajzon, 2012), and clay mineralogy (Zajzon et al., 2012) of the boundary succession.

The last occurrence of Triassic choristoceratid ammonoids, as well as the first appearance of Jurassic psiloceratid ammonites allow these sections in the Northern Calcareous Alps to be correlated with TJB successions in British Columbia (Canada; Ward et al., 2001, 2004; Williford et al., 2007), Nevada (USA; Guex et al., 2004, 2009; Ward et al., 2007) and Peru (Hillebrandt, 1994, 1997, 2000a, 2000b; Schoene et al., 2010). However , most marine NW European TJB successions lack representatives of Triassic ammonoids and the oldest psiloceratid ammonites, that have been recorded in the Northern Calcareous Alps, are also missing (Fig. 3). In addition, correlation with terrestrial successions is problematic. In order to accommodate correlation between terrestrial and marine TJB successions, an accessory marker for the base of the Jurassic was designated, namely the pollen taxon Cerebropollenites thiergartii, which has its first occurrence (FO) ca. $3 \mathrm{~m}$ below the FO of P. spelae in the Kuhjoch section (Fig. 2).

In addition to the biotic record of the GSSP section, bulk organic and compound specific C-isotopes with distinct negative excursions of $-5.5 \%$ and $-8.5 \%$ are coincident with the last occurrences of Triassic ammonoids and conodonts (Ruhl et al., 2009, 2011). Since its publication, another detailed $\delta^{13} \mathrm{C}_{\text {org }}$-record, obtained from an entirely marine succession at St Audrie's Bay in the United Kingdom (UK; Fig. 1) (Hesselbo et al., 2002) has been the reference section for TJB C-isotope stratigraphy (e.g. Guex et al., 2004; Whiteside et al., 2007, 2010; Ruhl and Kürschner, 2011; Lindström et al., 2012). The two most prominent negative C-isotope excursions (CIEs) in the UK record are a sharp negative excursion - defined as the "initial" CIE, that occurs close to the probable level of extinction of marine invertebrates in the Lilstock Formation, and a large negative shift - defined as the "main" CIE in the Blue Lias Formation that occurs just prior to the first occurrence of the typical Jurassic ammonite Psiloceras planorbis (Hesselbo et al., 2002, 2004) (Fig. 2). Because the UK 


\section{Kuhjoch/Ochsentaljoch \\ Lithostratigraphy}

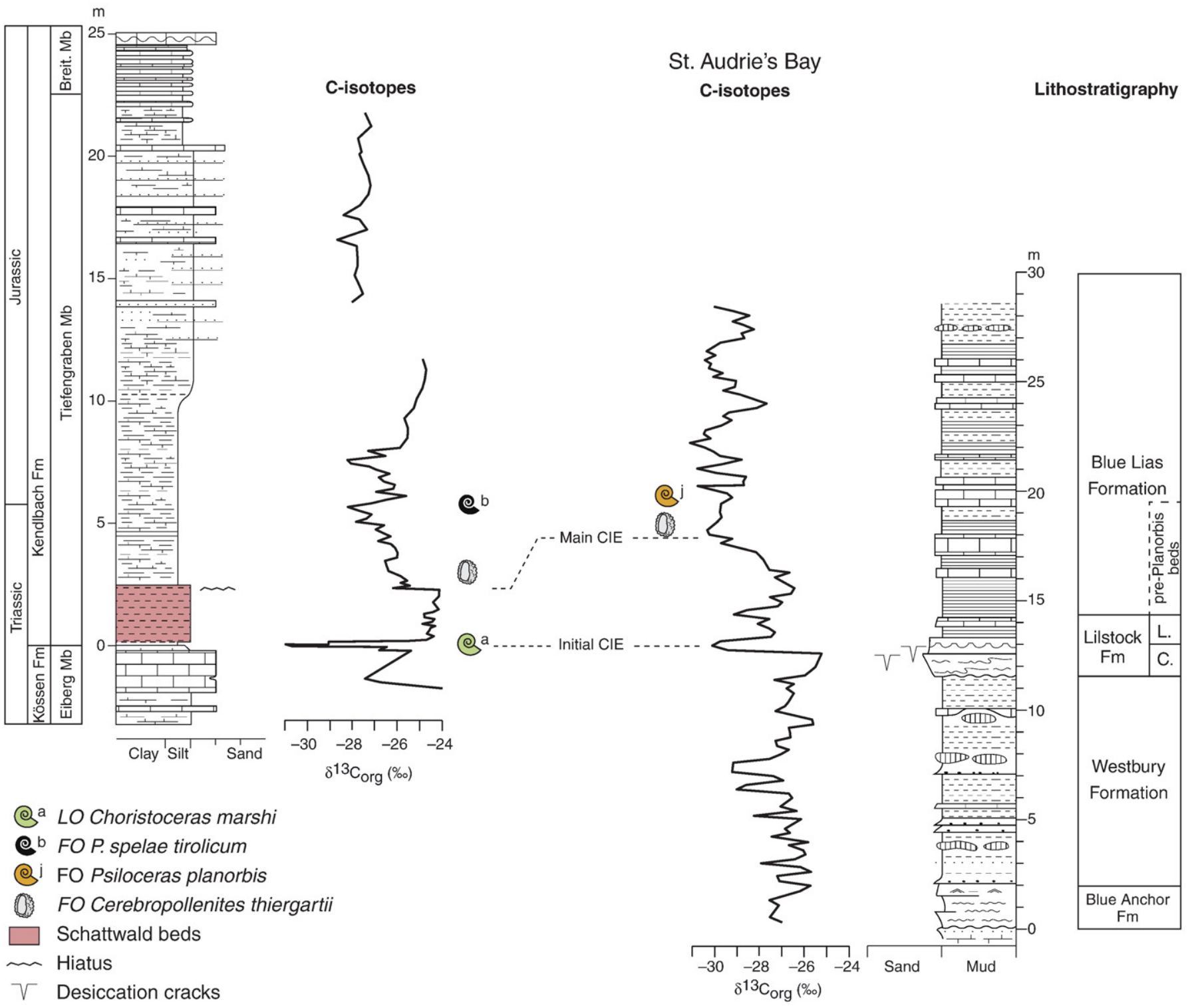

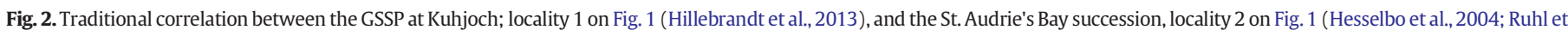
al., 2010b), based on ammonites, palynology and $\delta^{13} \mathrm{C}$-isotopes (mainly after Hillebrandt et al., 2013).

record lacks Psiloceras spelae, correlations between the UK record and the GSSP section at Kuhjoch have relied mainly on the first occurrence of the pollen Cerebropollenites thiergartii and C-isotope stratigraphy, correlating the "initial" CIE at St. Audrie's Bay with a sharp peak at the top of the Kössen Formation at Kuhjoch (Ruhl et al., 2011; Bonis and Kürschner, 2012) (Fig. 2). This correlation shown in Fig. 2, has been the basis for several papers concerning the end-Triassic event (e.g. Steinthorsdottir et al., 2011; Hillebrandt et al., 2013; Mander et al., 2013; Dal Corso et al., 2014).

However, some questions regarding the timing of the initial $\mathrm{CIE}$ and the onset of the biotic changes were raised when the $\mathrm{C}_{\text {org }}$-isotope and palynological record from St. Audrie's Bay were correlated with the thick cored TJB succession at Stenlille in Denmark (Lindström et al., 2012). There, it appeared that the most dramatic changes in both the marine and the terrestrial palynoflora commenced during the RicciisporitesPolypodiisporites (R-P) Zone (Lund, 1977), which in both the Stenlille and St. Audrie's Bay successions occurred prior to the "initial CIE" (Neg-II in Lindström et al., 2012; Lindström, 2016). The fact that major ecosystem changes began already prior to the "initial CIE" has also been demonstrated for bivalves (Mander et al., 2008), terrestrial vegetation (van de Schootbrugge et al., 2009), and calcareous nannoplankton and benthic foraminifera (Clémence et al., 2010). Thus, a revision of the correlation of TJB successions across Europe is warranted. Here, a new correlation of the TJB successions at Kuhjoch (Austria) and St. Audrie's Bay (UK), with those of the cored wells Stenlille-1/-2 and Rødby-1 (Denmark), Mariental, Schandelah and Mingolsheim (Germany) is presented, and its implications for the end-Triassic extinction events are discussed.

\section{Methods and means of correlation}

In this study we present sedimentological, biostratigraphical and geochemical analyses (organic C-isotopes) from the TJB successions at Stenlille-1/-2, Rødby-1, and Schandelah and Mingolsheim (Fig. 1). Some of the data used from these successions have already been published elsewhere (see references for each locality under "3. Brief stratigraphic review of key localities" below). In addition, a thorough review has been made of the published TJB successions at Kuhjoch 


\begin{tabular}{|c|c|c|c|c|}
\hline & $\begin{array}{c}\text { Ammonite } \\
\text { Zones }\end{array}$ & Northern Calcareous Alps & NW Europe & \\
\hline \multirow{12}{*}{ 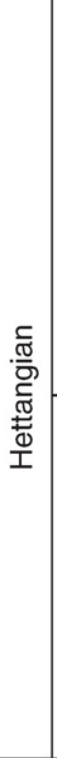 } & \multirow{6}{*}{ Planorbis } & Psiloceras naumanni & Caloceras johnstoni & \multirow{13}{*}{ 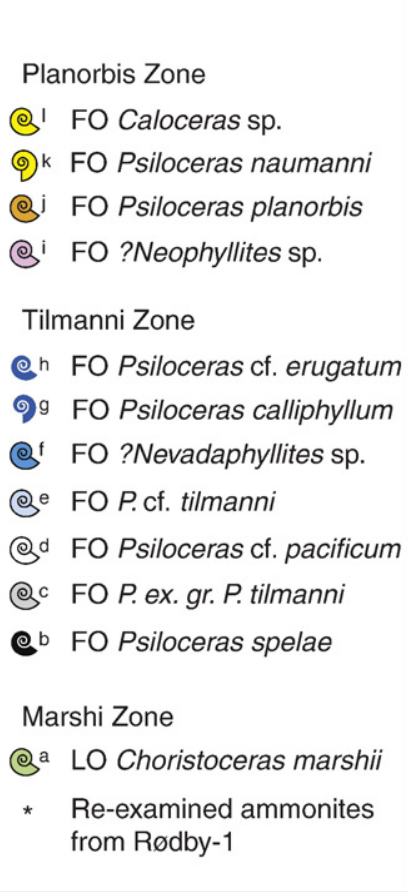 } \\
\hline & & \multirow{2}{*}{$\begin{array}{c}\text { Psiloceras costosum } \\
+ \\
\text { Psiloceras tenerum }\end{array}$} & Psiloceras plicatulum & \\
\hline & & & Psiloceras psilonotum & \\
\hline & & Psiloceras cf. planorbis & Psiloceras planorbis & \\
\hline & & Neophyllites imitans & Neophyllites antecedens & \\
\hline & & Neophyllites neumayri & Neophyllites imitans & \\
\hline & \multirow{6}{*}{ Tilmanni } & Psiloceras calliphyllum ๑g & Psiloceras erugatum & \\
\hline & & Psiloceras strongolum & \multirow{6}{*}{$\begin{array}{ll}\text { ?Nevadaphyllites sp.* }^{*} & \text { @ }^{\mathrm{f}} \\
\text { Psiloceras cf. tilmanni* } & \text { @ }^{\mathrm{e}}\end{array}$} & \\
\hline & & Psiloceras angulocostatum & & \\
\hline & & Psiloceras cf. pacificum & & \\
\hline & & Psiloceras ex. gr. tilmanni @ c & & \\
\hline & & Psiloceras spelae & & \\
\hline 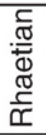 & Marshi & Choristoceras marshi & & \\
\hline
\end{tabular}

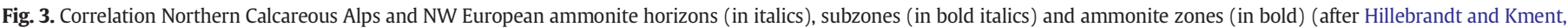

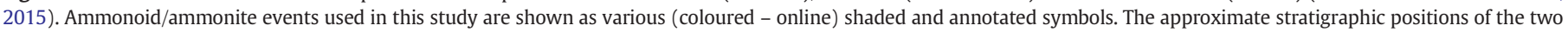
ammonites from Rødby-1 are included on the NW European chart.

(Hillebrandt et al., 2013), St. Audrie's Bay (Hesselbo et al., 2004; Bonis et al., 2010) and Mariental (Heunisch et al., 2010). The TJ-transition is known to be associated with substantial sea-level changes, the regression-transgression couplet first described by Hallam (1981). This profoundly affected deposition of strata within the European Epicontinental Seaway (EES), but is also recognized along the northern margin of the Tethys and needs to be taken into account when correlating TJB successions (Hallam and Wignall, 1999; Wignall and van de Schootbrugge, 2016). Since the first and last occurrences of taxa can be affected by differences in depositional environment and preservation, as well as sampling biases, correlation of TJB strata herein is based on a combination of multiple marine and terrestrial biostratigraphic events. In addition, lithological and sequence stratigraphical considerations have also been taken into account. The locations of the biostratigraphic events at Kuhjoch, St. Audrie's Bay, Stenlille and Rødby- 1 are marked on Figs. 4-7. Fig. 8 shows two herein re-described ammonites from Rødby-1, that are of stratigraphic importance. In addition, the locations of the biostratigraphic events at Mariental, Schandelah and Mingolsheim are shown on Figs. 9-11. It should be noted that not all events are recognized at all localities.

\subsection{Ammonites}

In the TJ marine macrofaunal record, ammonites are traditionally considered as one of the most reliable fossils for correlation. The most recent correlation between the ammonite stratigraphy of the Northern Calcareous Alps and that of NW Europe was presented in Hillebrandt and Kment (2015) (Fig. 3). The ammonoid/ammonite events used herein are primarily based on Hillebrandt and Krystyn (2009), Hillebrandt et al. (2013) and Hillebrandt and Kment (2015), and comprise the the last occurrence (LO) of the Late Triassic ammonoid Choristoceras marshi (in Peru and Nevada this event also includes the LO of C. crickmayi; Guex et al., 2004; Hillebrandt, 2000a, 2000b); followed by the successive FOs of psiloceratid ammonites commencing with Psiloceras spelae (Fig. 3).

\subsection{Palynology}

Palynological events are excellent tools for correlation, as palynomorphs may represent both marine and terrestrial ecosystems. Marine phytoplankton suffered severe losses during the end-Triassic event, especially within the dinoflagellate cyst family Suessiaceae. Rhaetogonyaulax rhaetica, a dinoflagellate cyst that disappeared during or shortly after the end-Triassic event, can be used as a marker by its last common (LCO), last consistent (LCON) and last occurrence (LO). Several spore and pollen taxa disappear during or just after the end-Triassic event and can be useful markers. Amongst these are the last occurrences of Granuloperculatipollis rudis, Rhaetipollis germanicus, Ovalipollis ovalis, Limbosporites lundbladiae, Semiretisporis gothae, Polypodiisporites polymicroforatus, and Ricciisporites tuberculatus. The last two taxa, $P$. polymicroforatus and $R$. tuberculatus, are known to be particularly abundant in late Rhaetian strata in NW Europe, hence, their respective quantitative occurrences are plotted for each locality on Figs. 4-7, 9-11. However, because last occurrences of palynomorphs may be affected by reworking, a number of spore-pollen taxa that have first occurrences (FO), first common (FCO) or first consistent occurrences (FCON) close to the TJB are used instead. This includes the FO of the accessory marker for the base of the Jurassic, the probable conifer pollen Cerebropollenites thiergartii, but also the FO/FCON/FCOs for the lycophyte spore Kraeuselisporites reissingeri, the FO of the fern spore Ischyosporites variegatus, and the Jurassic FCO of the pinacean conifer pollen Pinuspollenites minimus. Formal or informal palynozones for each locality are also shown on Figs. 4-7, 9-11.

\subsection{C-isotopes}

In addition to being interpreted as reflecting perturbations in the global carbon cycle, bulk organic C-isotopes have become a widely used tool for correlations. However, in order to correlate between C- 
isotope records, multiple age constraints are needed. The ideal scenario is that each $\mathrm{C}_{\text {org }}$-isotope excursion can be linked to one or several biostratigraphical events that can be traced regionally to globally. So far, this has not been the case for the TJB. None of the $\mathrm{C}_{\text {org }}$-isotope excursions recognized in e.g. the St. Audrie's Bay succession (Hesselbo et al., 2002), the Kuhjoch section (Ruhl et al., 2009, 2011; Ruhl and Kürschner, 2011), or the Stenlille succession (Lindström et al., 2012) have been specifically tied to a biostratigraphic event.

The new bulk organic $\delta^{13} \mathrm{C}$ record from Rødby- 1 was obtained by analyzing approximately $0.5 \mathrm{~g}$ of the samples by EA-IRMS at Iso-Analytical Laboratory in Cheshire, UK. The samples were decarbonized with $1 \mathrm{M}$ $\mathrm{HCl}$ to remove all carbonate, and the residues were washed twice with distilled water and subsequently dried at $60{ }^{\circ} \mathrm{C}$ prior to isotope analysis. All $\delta{ }^{13} \mathrm{C}$ values reported herein are expressed as per mil (\%) deviations from the ratio in the Vienna-defined Pee-Dee Belemnite (V-PDB).

\section{Brief stratigraphic review of key localities}

In addition to the TJB successions at Kuhjoch and St. Audrie's Bay, the reviewed localities consist of the cored Stenlille-1/-2 wells in the Danish Basin; the cored Rødby-1, Mariental and Schandelah wells in the North German Basin, and the cored Mingolsheim well in the South German Basin (Fig. 2).

\subsection{Kuhjoch}

The TJ boundary succession at Kuhjoch consists of two sections, Kuhjoch West and East, located in the western part of the Eiberg Basin in the Northern Calcareous Alps, and these are described in detail in Hillebrandt et al. (2013). At the TJB the Eiberg Basin was an intraplatform basin on the northern margin of the Tethys (Hillebrandt et al., 2013). The base of the Kuhjoch West section is located $3.8 \mathrm{~m}$ below the top of the Eiberg Member of the Kössen Formation, which consists of variably thick (up to $50 \mathrm{~cm}$ ) grey bioturbated limestone beds (Fig. 4). Spore-pollen assemblages from the Eiberg Member (Kössen Formation) were assigned to the Rhaetipollis-Limbosporites (RL) Zone sensu Kürschner et al. (2007) by Bonis et al. (2009), and correlated with the Rhaetipollis-Limbosporites (R-L) Zone of Lund (1977) (Fig. 2). Both the RL zone and the R-L Zone are recognized based on the common occurrence of the nominate taxa. Lindström (2016) considered the R-L Zone to represent the pre-extinction flora.

The uppermost Eiberg Member consists of a $20 \mathrm{~cm}$ thick limestone bed with higher clay content and darker colour than the beds below, and is referred to as the T-bed of Hillebrandt et al. (2007). In contrast, McRoberts et al. (2012) referred only the topmost $\sim 1 \mathrm{~cm}$ of the Eiberg Member; a black and bituminous and mm-laminated layer, rich in fish scales and bivalves, as the T-bed. According to Tanner et al. (2016), the T-bed sensu Hillebrandt et al. (2007) exhibits a pattern of decreasing carbonate and increasing alumina-silicate content interpreted as reflecting increasing anoxic conditions. Triassic ammonoids, ostracods and conodonts disappear within in the T-bed, marking the onset of the biotic crisis (Hillebrandt et al., 2013). A pronounced negative CIE, that encompasses the top of the T-bed and the lowermost $20 \mathrm{~cm}$ of the succeeding grey Tiefengraben Member of the Kendlbach Formation, was correlated by Ruhl et al. (2009) with the initial CIE of Hesselbo et al. (2002) at St. Audrie's Bay (Fig. 2). The lower half of this CIE exhibits high hydrogen index values and correlates with increased abundances of Classopollis meyerianus, while in its upper half the hydrogen index values are low and the palynological assemblages are instead dominated by high abundances of the prasinophycean alga Cymatiosphaera (Ruhl et al., 2010a).

The Kössen Formation is succeeded by grey to brownish clay-rich marls and partly laminated marls in the basal part of the Tiefengraben Member (Hillebrandt et al., 2013). These grey beds are overlain by approximately $2 \mathrm{~m}$ of reddish silty clays, the Schattwald beds, which in turn are succeeded again by grey beds of the Tiefengraben Member (Fig.
4). The Schattwald beds are interpreted as having been deposited during the peak of a regression that commenced at the top of the Kössen Formation (McRoberts et al., 2012). The lack of macrofauna and presence of a depauperate foraminifer fauna consisting of the finely agglutinated siliceous Hippocrepina in the Schattwald beds have been interpreted as reflecting unfavourable conditions for calcifying organisms (McRoberts et al., 2012; Hillebrandt et al., 2013). In addition, dinoflagellate cysts are also virtually absent in the Schattwald beds, and Rhaetogonyaulax rhaetica has its LCO within this unit (Fig. 4). Spore-pollen assemblages of this interval differ substantially from those from the Kössen Formation, and were assigned to the Rhaetipollis-Porcellispora (RPo) Zone (Kürschner et al., 2007; Bonis et al., 2009; Hillebrandt et al., 2013). This zone contains abundant fern spores assigned to Deltoidospora and Polypodiisporites polymicroforatus. Within the middle and upper part of the Schattwald beds cheirolepidiacean conifer pollen (primarily Classopollis) almost disappeared, while the probable schizacean fern spore $P$. polymicroforatus continued to increase in abundance (Bonis et al., 2009; Hillebrandt et al., 2013; Lindström, 2016). A local fault, evident as a sharp shift in both the palynological and the C-isotope records, with a sharp negative CIE, is present in the uppermost part of the Schattwald beds (Hillebrandt et al., 2013) (Fig. 4). Hillebrandt et al. (2013) estimated that ca. $0.5 \mathrm{~m}$ of the upper Schattwald beds are missing at Kuhjoch West. Strata corresponding to the hiatus are preserved at Kuhjoch East, and these contain assemblages assigned to the Trachysporites-Porcellispora (TPo) Zone of Kürschner et al. (2007). The TPo zone shows an initial continued dominance of $P$. polymicroforatus and Deltoidospora, but with a gradual increase in Classopollis (Fig. 2). Bonis et al. (2009) correlated both the RPo and TPo zones with the Ricciisporites-Polypodiisporites Zone by Lund (1977), and these zones were considered to represent the extinction flora by Lindström (2016). Ricciisporites tuberculatus fluctuates within these zones, but increases in abundance in the overlying grey Tiefengraben Member (Fig. 4). High abundances of Polypodiisporites polymicroforatus is, however, restricted to the uppermost RL Zone and most of the RPo Zone, i.e. more or less restricted to the Schattwald beds (Fig. 4).

The succeeding grey Tiefengraben Member is interpreted to have been deposited during a long-term transgression, and the C-isotope record continues to exhibit more depleted values. The interval between 2.3 and $8.0 \mathrm{~m}$ was assigned to the Trachysporites-Heliosporites $(\mathrm{TH})$ zone (Hillebrandt et al., 2013) (Fig. 4). The base of this zone is marked by the FOs of Kraeuselisporites reissingeri (Heliosporites altmarkensis) and Ischyosporites variegatus. At $2.6 \mathrm{~m}$, Cerebropollenites thiergartii is recorded for the first time (Fig. 4). Bonis et al. (2009) correlated the TH zone with the Pinuspollenites-Trachysporites Zone of Lund (1977), however, since Pinuspollenites minimus does not have its FCO until the base of the succeeding Trachysporites-Pinuspollenites (TPi) zone, Lindström (2016) instead correlated the TH zone with the so called Transition zone by Lund (1977) and referred it to the recovery phase. The first occurrence of Psiloceras spelae tirolicum, and hence the base of the Jurassic, is located in the middle of the TH zone, $3.2 \mathrm{~m}$ above the top of the Schattwald beds (Fig. 4; Hillebrandt et al., 2013).

The overlying TPi zone was correlated with the PinuspollenitesTrachysporites Zone of Lund (1977) and assigned to the post-extinction phase (Lindström, 2016). In the lower part of this zone, at $8.0-8.8 \mathrm{~m}$, ammonites assigned to $P$. ex. gr. $P$. tilmanni occur for the first time, and at approximately the same level $R$. rhaetica is registered for the last time (Fig. 4). The upper boundary of the TPi zone is not defined and only the level up to $16 \mathrm{~m}$ was investigated palynologically (Bonis et al., 2009; Hillebrandt et al., 2013). At $12.1 \mathrm{~m}$ the ammonite Psiloceras cf. pacificum is registered. According to Hillebrandt and Kment (2015) this indicates the lower Tilmanni Zone. The uppermost ammonite level in the Kendlbach Formation is the Calliphyllum bed, which is highly condensed and contains Psiloceras strongulum, $P$. calliphyllum, and $P$. naumanni, which according to Hillebrandt and Kment (2015) corresponds to the upper Tilmanni Zone and a large portion of the Planorbis Zone (Fig. 3). The $\delta^{13} \mathrm{C}_{\text {org }}$-record for the upper part of the grey Tiefengraben Member is from the neighbouring Ochsentaljoch locality, 
Kuhjoch/Ochsentaljoch
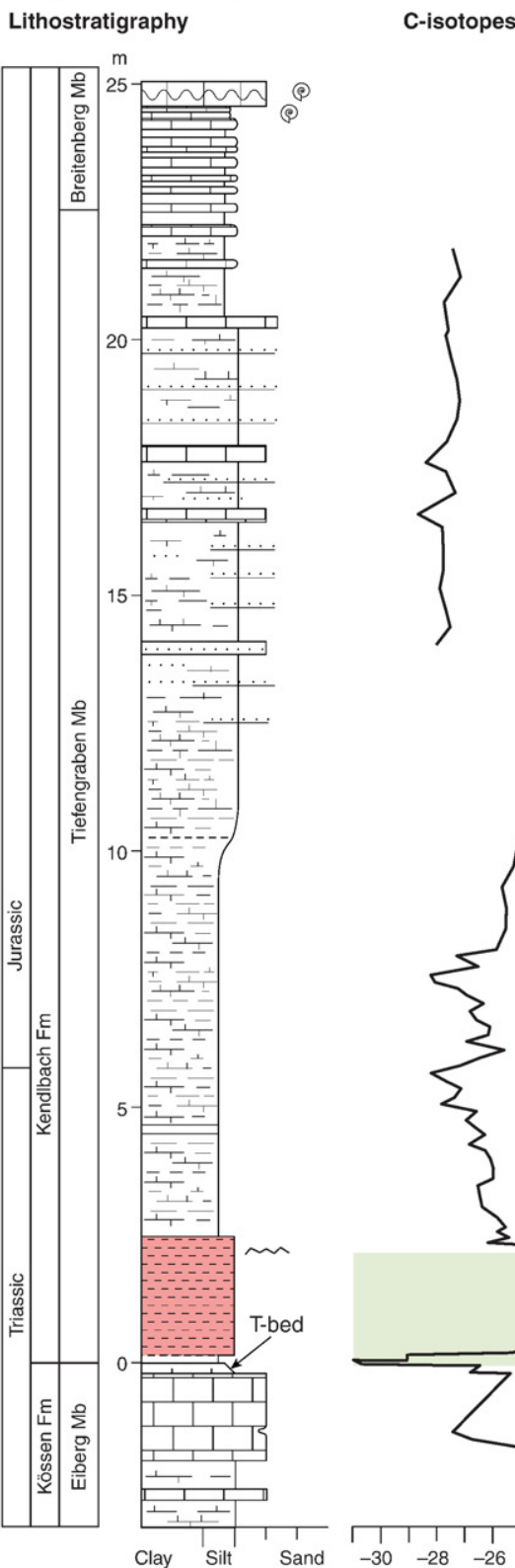

Palynology

Events

Ammonite

zones
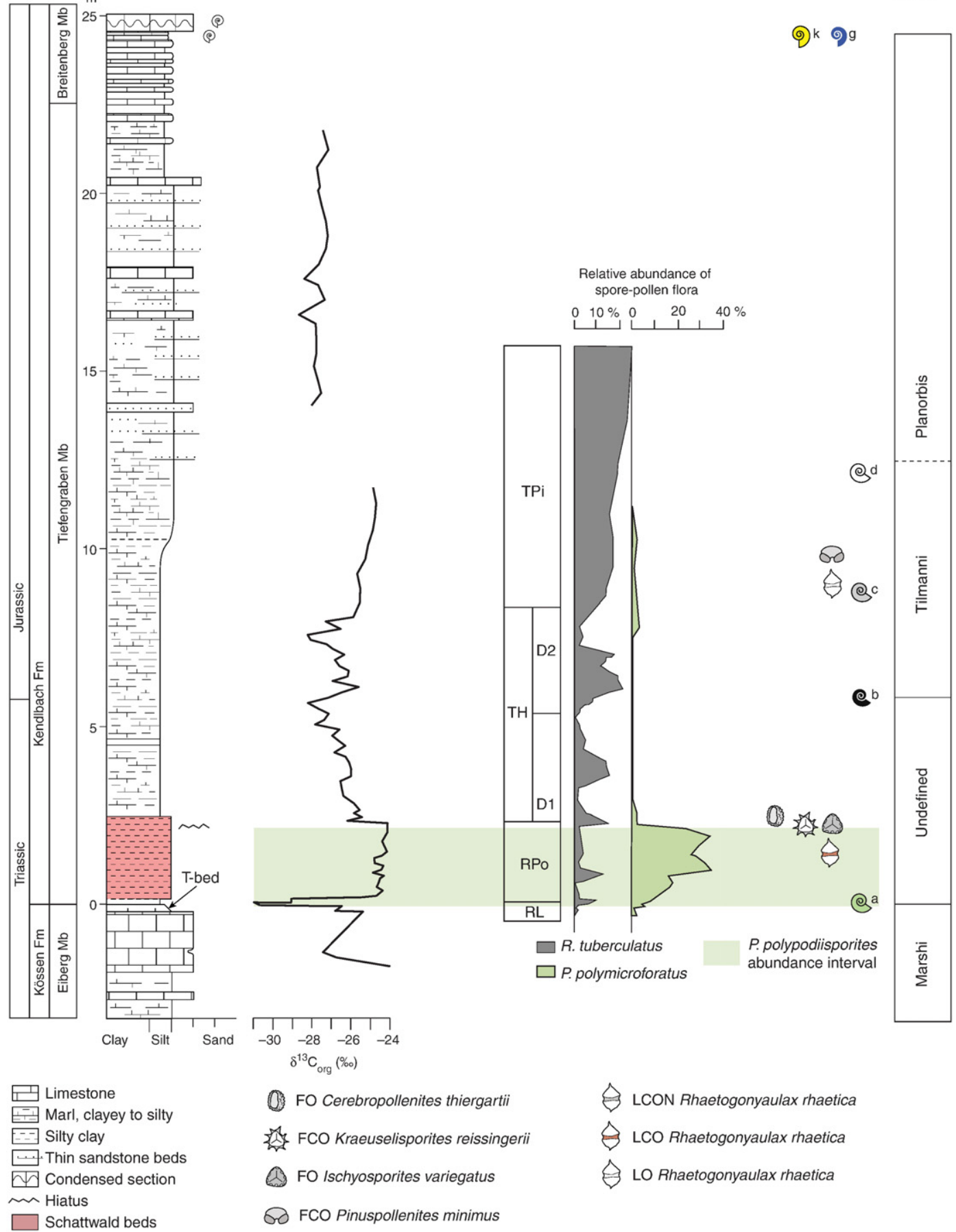

$\Leftrightarrow$ LCON Rhaetogonyaulax rhaetica

$\otimes$ LCO Rhaetogonyaulax rhaetica

$\Leftrightarrow$ LO Rhaetogonyaulax rhaetica

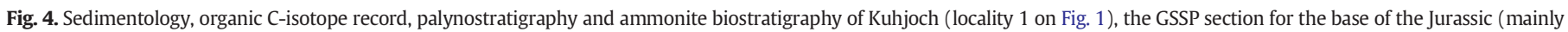

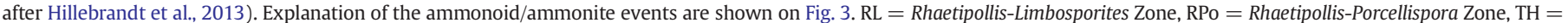
Trachysporites-Heliosporites Zone, TPi = Trachysporites-Pinuspollenites Zone.

and exhibits a return to more negative values than those registered in the interval between the FOs of $P$. ex. gr. P. tilmanni and $P$. cf. pacificum (Ruhl et al., 2009; Hillebrandt et al., 2013).

\subsection{St. Audrie's Bay}

The marine succession at St. Audrie's Bay in England encompasses strata representing the Blue Anchor, Westbury, Lilstock, and Blue Lias Formations, and the sedimentology, magneto-, carbon isotope-, and bio-stratigraphy have previously been described by several authors (see e.g. Hesselbo et al., 2002, 2004; Hallam and Wignall, 2004; Hounslow et al., 2004; Mander et al., 2008; Wignall and Bond, 2008; Bonis et al., 2010) (Fig. 5).

The base of the succession in Hesselbo et al. (2002, 2004) encompasses two meters of thinly laminated heteroliths of the topmost Blue Anchor Formation, interpreted to have been deposited in a shallow marine environment during the start of a Late Triassic transgression (Hesselbo et al., 2004). The succeeding Westbury Formation comprises 

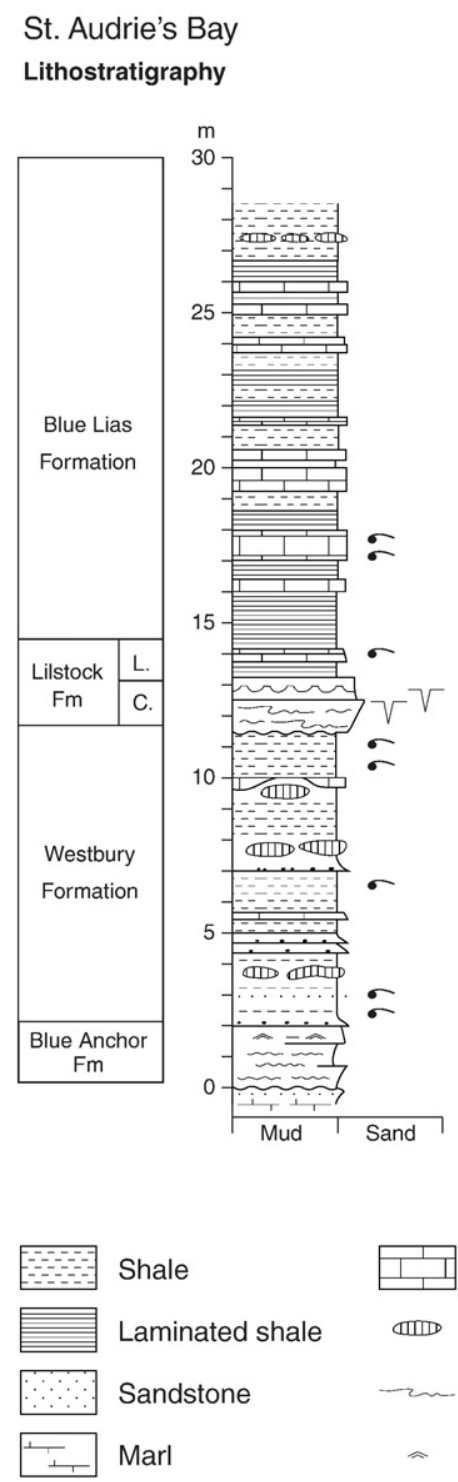

\section{C-isotopes}
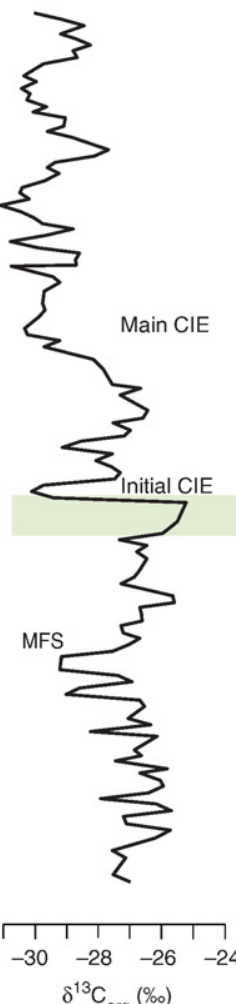

$\delta^{13} \mathrm{C}_{\text {org }}(\% \circ)$

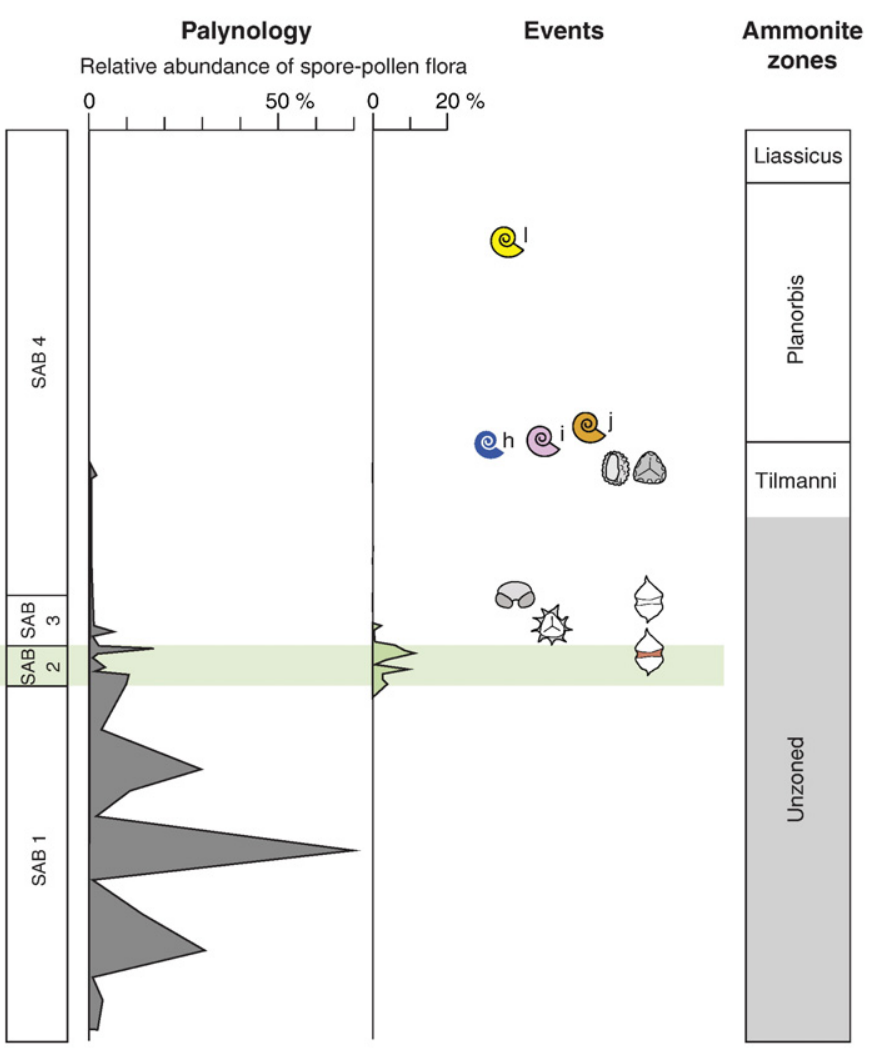

P. polypodiisporites abundance interval
R. tuberculatus

P. polymicroforatus

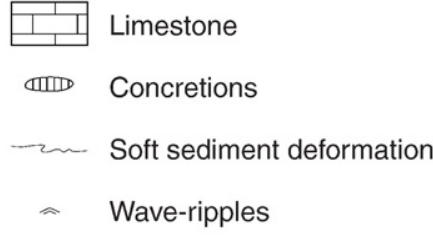

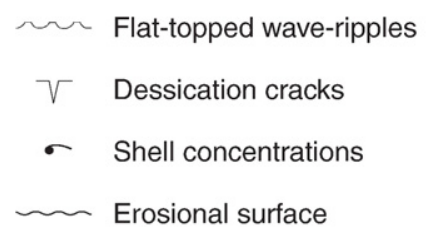

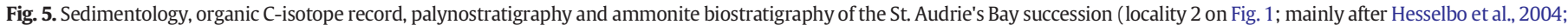

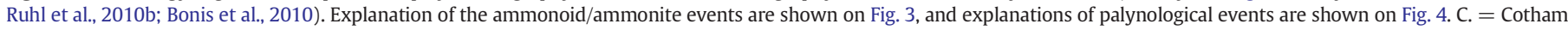
Member, L. = Langport Member.

predominantly dark coloured, but not particularly organic rich, mudstone with interstratified beds of siltstone, phosphatic conglomerate and carbonate concretions. It is interpreted as having been deposited under marine conditions, mostly under deeper conditions than the underlying strata. A maximum flooding surface is present somewhere in the middle of the Westbury Formation, probably close to the highest TOC values (Hesselbo et al., 2004). These occur just below a first negative carbon isotope excursion in the middle Westbury Formation (Fig. 5). Spore-pollen assemblages from the upper Blue Anchor Formation and the Westbury Formation, characterized by high abundances of Classopollis, Ricciisporites tuberculatus and Ovalipollis, were assigned to the informal SAB1 zone by Bonis et al. (2010).

The transition from the Westbury Formation to the Cotham Member is a shallowing upwards succession. Mudstones, fine-grained sandstones and limestones of the lower Cotham Member are interpreted as shoreface equivalents of the offshore Westbury Formation deposited during a regression (Hesselbo et al., 2004). During this interval the Cisotope values are more positive (Fig. 5). The transition between the Westbury Formation and the Cotham Member is also complicated by the occurrence of soft-sediment deformation structures, interpreted as seismites (Simms, 2003; Lindström et al., 2015). The shallowing upward succession of the lower Cotham Member culminated in an erosional surface displaying mud-cracks up to $90 \mathrm{~cm}$ deep, separating the lower and upper Cotham Member (Hesselbo et al., 2004; Fig. 5). The thinly interbedded mudstones, siltstones and fine-grained calcareous sandstones of the upper Cotham Member are interpreted as coastal deposits formed during a subsequent relative sea-level rise (Hesselbo et al., 2004). Bonis et al. (2010) assigned spore-pollen assemblages to the informal SAB2 zone, comprising the Cotham Member (Lilstock Formation) to just below the initial negative $\mathrm{C}$-isotope excursion by Hesselbo et al. (2002), including two assemblages from the upper Cotham Member above the unconformity. Because of the unconformity a part of the zone may be missing (Lindström et al., 2012; Lindström, 2016). The SAB2 zone is characterized by increased spore abundance, while pollen taxa decrease markedly in its uppermost part (Bonis et al., 2010) (Fig. 5). Polypodiisporites polymicroforatus is particularly abundant within this restricted interval in the lower Cotham Member, and decreases abruptly in the upper Cotham Member (Fig. 5). Lindström (2016) considered the SAB2 zone to represent the extinction palynoflora. The amount of Ricciisporites tuberculatus varies markedly throughout the Westbury Formation, but shows an overall upward decreasing trend in the Lilstock Formation, exhibiting very low 
abundances in the lowermost Blue Lias Formation (Fig. 5). In addition, assemblages from the upper part of the Westbury Formation and the lower part of the Cotham Member are dominated by dinoflagellate cysts (mainly $R$. rhaetica and D. priscum), with the LCO of R. rhaetica occurring within the Cotham Member prior to the "initial" CIE (e.g. Warrington in Hounslow et al., 2004; Bonis et al., 2010). Mander et al. (2008) placed the extinction of marine invertebrates in the upper Westbury Formation to lower Cotham Member interval.

The upper Cotham Member and the succeeding lower Langport Member are devoid of shelly fossils and were considered to represent a "dead zone" following the extinction (Mander et al., 2008). Palynological assemblages from the upper Cotham Member and the Langport Member, were assigned to the informal SAB3 zone by Bonis et al. (2010). This zone is generally dominated by Classopollis spp., alternating with assemblages dominated by spores (Bonis et al., 2010), and was considered to represent the recovery flora (Lindström, 2016). Kraeuselisporites reissingerii has its FCO within this zone (Fig. 5).

There is a very sharp shift in the palynological record at the base of the Blue Lias Formation, marking the base of the SAB4 zone of Bonis et al. (2010). According to Wignall and Bond (2008) there is a regional, poorly understood hiatus at the top of the Langport Member, which is more evident at some localities. The base of the succeeding Blue Lias Formation marks a rapid flooding (Wignall and Bond, 2008), and coincides with a second smaller CIE within the "initial" CIE. The C-isotope record from the succeeding Pre-Planorbis beds in the Blue Lias Formation exhibits markedly less depleted values. This interval of more positive Cisotope values is succeeded by the "main" negative CIE that occurs in association with the onset of organic-rich deposition just prior to the first occurrence of typical Jurassic ammonites (Fig. 5). The oldest psiloceratid ammonite Psiloceras cf. erugatum, indicative of the topmost Tilmanni Zone, is followed by the FOs of ?Neophyllites sp. and Psiloceras planorbis that are both typical of the lower Planorbis Zone (Figs. 3, 5).

The SAB4 zone of Bonis et al. (2010) covers the Blue Lias Formation and is totally dominated by Classopollis spp. The FCO of Pinuspollenites minimus is in the lowermost assemblage from the Blue Lias Formation. The FO of Cerebropollenites thiergartii is registered within the "main" CIE ca. $0.8 \mathrm{~m}$ below the FO of psiloceratid ammonites, and at the same level Ischyosporites variegatus was also registered (Bonis et al., 2010). The FO of Psiloceras cf. erugatum at ca. $19.3 \mathrm{~m}$ can be correlated with the $P$. calliphyllum horizon in the Northern Calcareous Alps, and thus represents the uppermost Tilmanni Zone (Fig. 3). The succeeding FO of ?Neophyllites sp. (at ca. $19.5 \mathrm{~m}$ ) and the FO of Psiloceras planorbis (at ca. $19.9 \mathrm{~m}$ ) represents the lowermost Planorbis Zone. Caloceras johnstoni is first recorded at ca. $26 \mathrm{~m}$ indicating the uppermost Planorbis Zone (Fig. 3).

\subsection{Stenlille}

The Stenlille-1 well was drilled in 1980 on the Danish island Sjælland (Zealand). The fully cored TJB succession belongs to the Gassum and Fjerritslev Formations (Nielsen, 2003) (Fig. 6). Parts of the succession have previously been described by means of sedimentology, sequence stratigraphy, geophysical log-patterns, core interpretations, and biostratigraphic analyses (Pedersen, 1985; Hamberg and Nielsen, 2000; Nielsen, 2003). The Gassum Formation consists of interbedded fine- to medium-grained, occasionally coarse-grained and pebbly sandstones, heteroliths, mudstones and few thin coaly beds (Bertelsen, 1978; Michelsen and Nielsen, 1991), formed in a shallow marine to coastal environment. It is succeeded by the lowermost part of the Fjerritslev Formation which consists of dark grey shale. This shale unit was deposited during the late Rhaetian transgression and the maximum flooding surface (MFS 7) of Nielsen (2003) is located in the middle of the ca. $3 \mathrm{~m}$ thick shale (Fig. 6). Palynological assemblages of the Gassum Formation and the dark grey shale at the base of the Fjerritslev Formation are assigned to the GranuloperculatipollisClassopollis-Perinopollenites (GCP) zone, which is dominated by conifer pollen, primarily the nominate taxa (Lindström, 2016). These pollen groups decrease in abundance upwards within the dark grey shale and are virtually absent in the succeeding zone. Dinoflagellate cysts also decrease dramatically in abundance and Rhaetogonyaulax rhaetica has its LCO in the middle of the dark grey shale. The $\delta^{13} \mathrm{C}_{\text {org }}$ record of Stenlille exhibits slightly decreasing values upwards through the Gassum Formation and culminates in a negative peak in the lowermost part of the dark grey shale. However, above this negative CIE, the

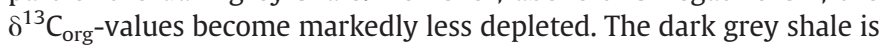
succeeded by greenish grey siltstones and fine-grained sandstones, the event beds of Lindström et al. (2012). The palynoflora from the grey siltstone interval belongs to the Polypodiisporites-RicciisporitesDeltoidospora (PRD) zone, which differs significantly from the previous zone. It is dominated by Polypodiisporites polymicroforatus, Ricciisporites tuberculatus and Deltoidospora spp., while conifer pollen are virtually absent (Lindström, 2016). In the Stenlille record R. tuberculatus is common to abundant in the GCP zone and remains relatively abundant throughout the grey siltstone interval (Lindström, 2016). High abundances of Polypodiisporites polymicroforatus, on the other hand, appear to be restricted to the PRD zone and it decreases markedly above this zone (Fig. 6). The grey siltstone interval represents a regression and is interpreted to have been deposited in a shallow marine environment. It is virtually devoid of trace fossils. It further contains multiple levels of soft-sediment deformations structures, seismites, which can be correlated with similar disturbed intervals across Europe, including that at St. Audrie's Bay (Lindström et al., 2015). During the grey siltstone interval the $\delta{ }^{13} \mathrm{C}_{\mathrm{org}}$-values fluctuate but are generally less depleted than the ones from the Gassum Formation. In the uppermost part of the interval Cerebropollenites thiergartii is registered for the first time (Fig. 6).

The grey siltstone is followed by marine claystones, mudstones and fine-grained sand intervals, deposited during another transgressive event. A marked negative 3\% excursion occurs at its base, with succeeding, although somewhat less depleted values. The palynofloras are interpreted to reflect floral recovery, and are assigned to the Calamospora-Conbaculatisporites-Monosulcites (CCM) and Perinopollenites-Deltoidospora-Stereisporites (PDS) zones (Lindström, 2016). Kraeuselisporites reissingerii and Ischyosporites variegatus have their FOs in the lowermost part of the PDS zone, and in its upper part the dinoflagellate cyst $R$. rhaetica occurs for the last time (Fig. 6). The FCO of Pinuspollenites minimus marks the lower boundary of the Deltoidospora-Perinopollenites-Pinuspollenites (DPPi) zone, which is dominated by Deltoidospora spp., Perinopollenites elatoides and $P$.

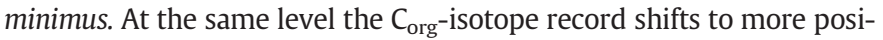
tive values. Lindström (2016) correlated the DPPi zone and the succeeding Perinopollenites-Pinuspollenites (PPi) zone with the Pinuspollenites-Trachysporites Zone of Lund (1977), and placed these zones within the post-extinction phase. Within the PPi zone, the $\mathrm{C}_{\mathrm{org}}{ }^{-}$ isotope values again become more depleted, reaching a minimum between two levels with observed ammonites (fragments?) in the Stenlille-2 succession (Fig. 6).

\subsection{Rødby}

The cored Rødby-1 Well was drilled in 1952 by the Danish American Prospecting Company (DAPCo) on the island Lolland in southeastern Denmark (Nørvang, 1957). Thus, the well is situated on the southern flank of the Ringkøbing-Fyn High in the northern part of the North German Basin. Due to its geographic position close to the Danish Basin, both the German and Danish lithostratigraphies have been applied to the TJB succession and are shown on Fig. 7. The Late Triassic-Early Jurassic palynology of the Rødby-1 well was studied by Lund (1977) and formed the basis of his widely used palynostratigraphic zonation. In this study, the Rødby-1 palynological record of Lund (1977) has been supplemented with additional palynology, sedimentology and $\mathrm{C}_{\text {org-iso- }}$ topes (Fig. 7). In addition, two ammonites originally assigned to Psiloceras planorbis (Sorgenfrei and Buch, 1964) have been re-examined herein. 


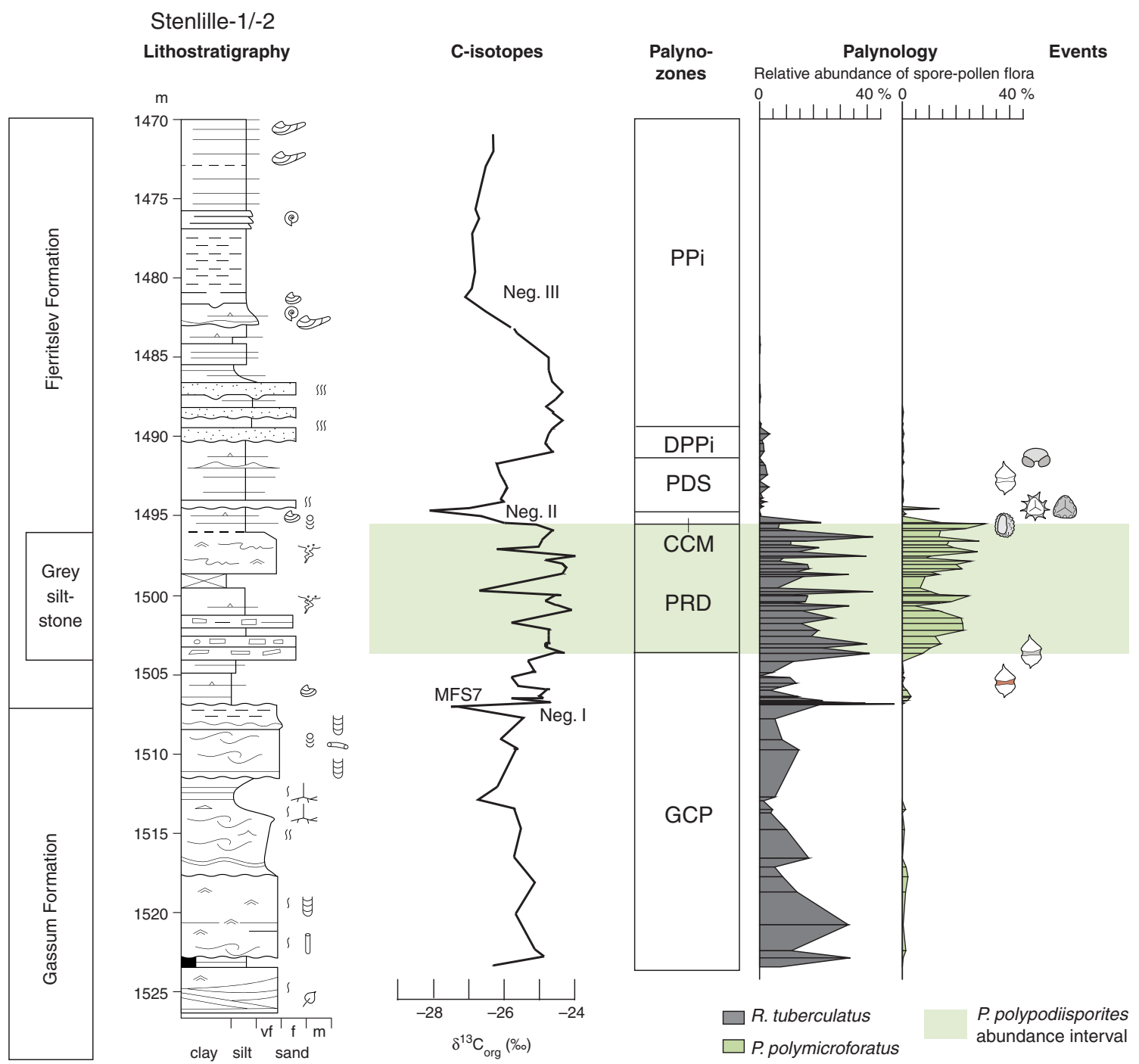

Legend for Stenlille1, 2 and Rødby-1

Coal

- - Coal clasts

Clay clasts

$\star \quad$ Pyrite

Sedimentary structures

Lamination
Weak lamination

Trace fossils and biota

$\begin{array}{cl}\text { s-ss } & \text { Weak to intense bioturbation } \\ \forall & \text { Diplocraterion isp. } \\ \varnothing & \text { Plant fragments } \\ \infty & \text { Planolites isp. } \\ +\frac{1}{8} & \text { Chondrites isp. } \\ \& & \text { Teichichnus isp. } \\ \odot & \text { Ammonites }\end{array}$

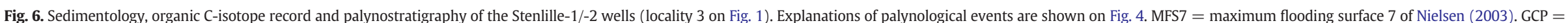

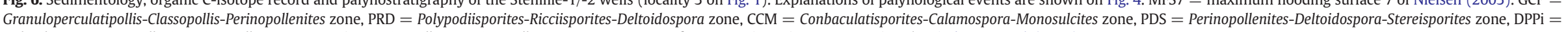
Deltoidospora-Perinopollenites-Pinuspollenites zone, PPi = Perinopollenites-Pinuspollenites zone. Neg. I-III refer to negative C-isotope excursions by Lindström et al. (2012) 
Rødby-1

Lithostratigraphy

b.KB 1730

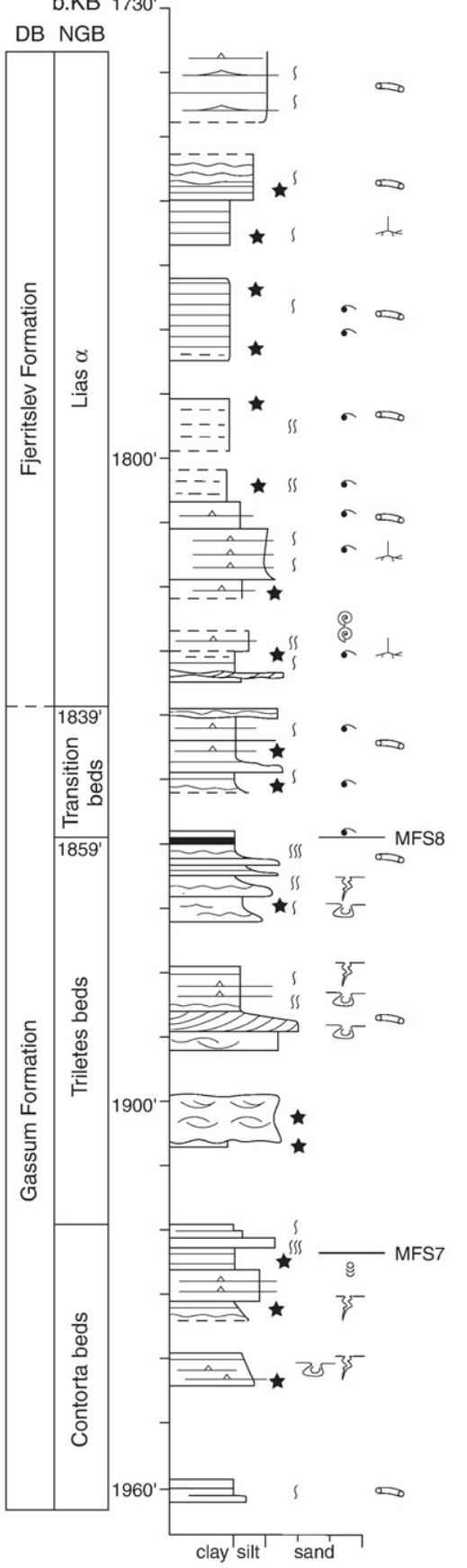

NGB North German Basin (Lund 1977)

DB Danish Basin (Nielsen \& Japsen 1991, Poulsen 1966)
C-isotopes

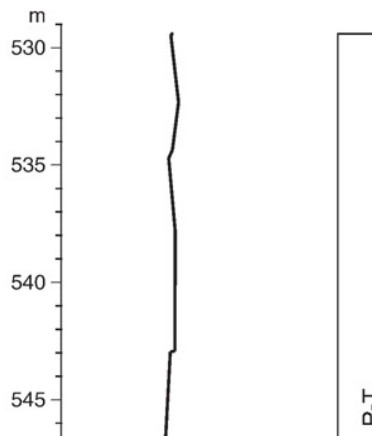

Palynology

Events Ammonite

Relative abundance of spore-pollen flora
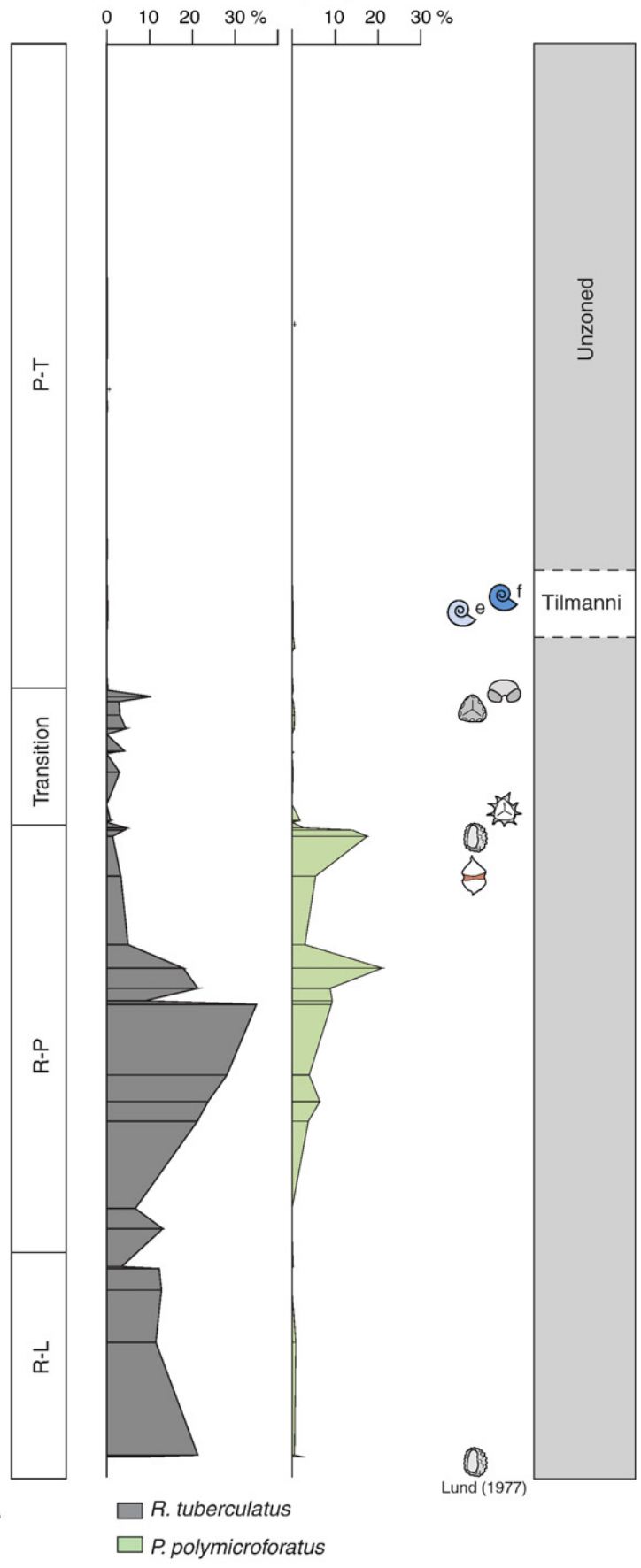

zones

R. tuberculatus

$\square$ P. polymicroforatus

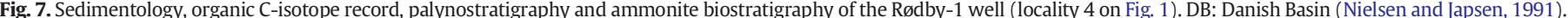

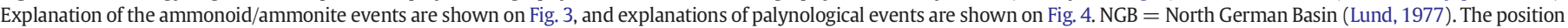

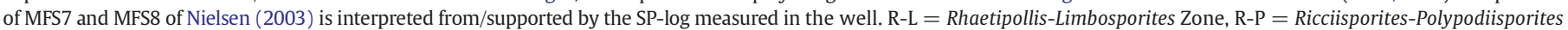
Zone, P-T = Pinuspollenites-Trachysporites Zone. Legend on Fig. 6.

The succession below 584.9 m (depth below Kelly Bushing) was assigned to the Contorta beds by Lund (1977) and referred to his Rhaetipollis-Limbosporites (R-L) Zone (Fig. 7). The sediments of the succeeding Triletes beds are generally greenish-grey in colour, and contain multiple soft-sediment deformations, interpreted as seismites (Lindström et al., 2015). The Triletes beds belong to the RicciisporitesPolypodiisporites (R-P) Zone (Lund, 1977; Hansen, 2013; Lindström et al., 2015). The LCO of $R$. rhaetica is at $570.1 \mathrm{~m}$ within the Triletes beds.
Ricciisporites tuberculatus decreases in abundance already in the middle part of this zone, while P. polymicroforatus continues to exhibit relatively high amounts to the top of this zone, after which it drops markedly in abundance (Fig. 7). A little higher, at 567.5 m, Cerebropollenites thiergartii was recorded for the first time. However, it should be noted that Lund (1977) recorded C. thiergartii as low as $598.2 \mathrm{~m}$. The interval between $566.6 \mathrm{~m}$ and $560.5 \mathrm{~m}$ were not assigned lithostratigraphically by Lund (1977) as its brownish clay differed in colour to the underlying 
Triletes beds. In the lowermost part of the transition beds (566.3 m) Kraeuselisporites reissingerii is recorded for the first time, coinciding with a small negative C-isotope excursion. In the uppermost part of the transition beds, the FO of Ischyosporites variegatus is registered. Lias $\alpha$ was recognized from $560.5 \mathrm{~m}$ and upwards, based on its dark grey clays (Lund, 1977). The FCO of Pinuspollenites minimus marks the lower boundary of the Pinuspollenites-Trachysporites Zone. A little higher in the succession the two ammonites previously assigned to Psiloceras planorbis occur at $556.9 \mathrm{~m}$ and $556.3 \mathrm{~m}$, respectively, and these are re-examined below. Their occurrences are succeeded by a marked shift to more depleted $\delta^{13} \mathrm{C}_{\text {org }}$-values.

\subsubsection{Re-examination of the psiloceratids in Rødby-1}

Two ammonites were originally identified as Psiloceras planorbis (Sorgenfrei and Buch, 1964). Prior to the ratification of the base of the Jurassic, $P$. planorbis was traditionally considered the oldest Jurassic ammonite, and it is the index taxon of the Planorbis Zone and Subzone (e.g. Page, 2003). J.H. Callomon (oral communication in Poulsen, 1996) confirmed the identifications of the Rødby- 1 material. However, notes stating that 'previous identifications seem ok' by J.H. Callomon, accompanying one of the samples indicate, that the re-examination was nothing but superficial and has encouraged a more detailed re-examination in this study. Since that time there has been quite a development within the understanding of the faunal succession of psiloceratids from the base of the Jurassic and in the lower Hettangian (e.g. Hillebrandt, 2000a, 2000b; Guex et al., 2004; Hillebrandt and Krystyn, 2009: Hillebrandt and Kment, 2015).

In general psiloceratids, including $P$. planorbis, are characterized as (markedly) evolute with the umbilical diameter markedly larger than the whorl height (as observed in figured psiloceratids in e.g. Guex, 1995; Bloos, 1999b, 2004; Hillebrandt and Kment, 2015). However, older forms of psiloceratids are involute to various degrees. The taxon Psiloceras spelae Guex described from Nevada, North America; now reported to be the earliest Jurassic psiloceratid with its European subspecies P. spelae tirolicum Hillebrandt and Krystyn from Austria considered to be the oldest form, is also characterized as being involute. Another characteristic of $P$. spelae is that it has tuberculate inner whorls.

Although the two re-examined specimens from the Rødby- 1 core are both poorly preserved and fragmented; with only a minute part of the suture line (part of a lobe) visible in one specimen, it is clear that they are both involute and thus differ from P. planorbis (Fig. 8). The specimen from $556.9 \mathrm{~m}$ has a whorl height slightly larger than, close to equal with, the umbilical diameter and an umbilicus/diameter ratio $(U=\mathrm{u} / \mathrm{D})$ of 0.36 (Fig. 8a, A; MGUH 31587). The other specimen from

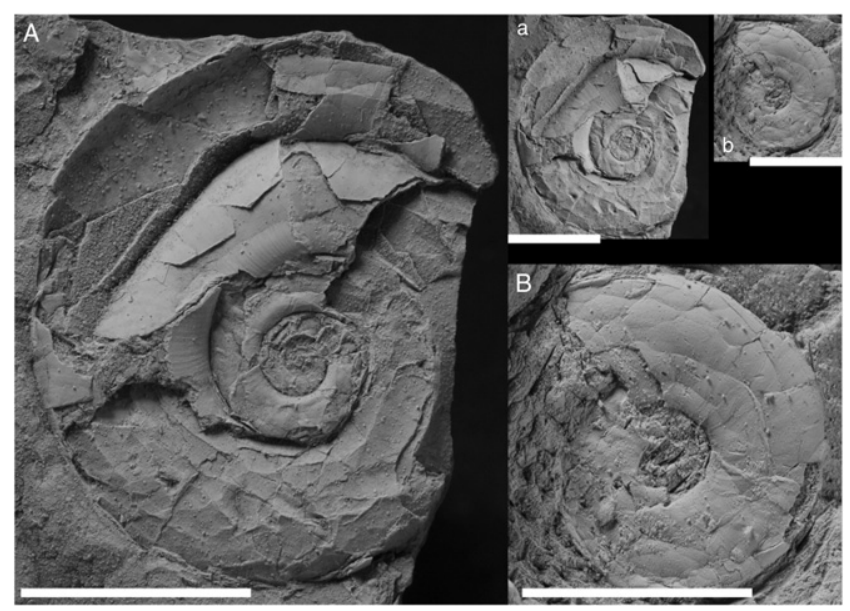

Fig. 8. Psiloceratid ammonites in the Rødby- 1 core. A, a: Psiloceras cf. tilmanni Lange, MGUH 31587, from $556.9 \mathrm{~m}$ shown in natural size (a) and enlarged $\times 2.5$ (A). B, b: ?Nevadaphyllites sp., MGUH 31588, from $556.3 \mathrm{~m}$ shown in natural size (b) and enlarged $\times 2.5$ (B). depth $556.3 \mathrm{~m}$ is markedly more involute with the umbilicus/diameter ratio being 0.23 , and the whorl height/diameter ratio $(\mathrm{H}=\mathrm{h} / \mathrm{D})$ being 0.4 (Fig. 8b, B; MGUH 31588). The Rødby-1 ammonites differ from $P$. spelae in lacking tuberculate inner whorls. They both appear to be smooth throughout, except for fine growth lines (best seen in Fig. 8A).

\subsubsection{Specimen MGUH31587 (depth $556.9 \mathrm{~m}$ ): Psiloceras cf. tilmanni Lange}

The specimen from depth $556.9 \mathrm{~m}$ closely resembles $P$. tilmanni Lange as figured in Guex (1995), plate 6 and Figs. 2-3 therein). Another close match is found in a specimen assigned to Psiloceras pacificum Guex and figured by Hillebrandt and Krystyn (2009, their Figs. 10, 15a and b), which appears to be wholly smooth, to have equal whorl height and umbilical diameter and a u/D-ratio of 0.37 (measured on the illustration), i.e. very close to the specimen from level $556.9 \mathrm{~m}$ in Rødby-1. The above mentioned $P$. pacificum specimen was collected from the type horizon of the holotype of Psiloceras pacificum Guex (bed Z-7 of section 1, New York Canyon; Guex, 1995) and was also referred to that species. However, Hillebrandt and Krystyn's (2009) specimen appears to be more involute than the series of $P$. pacificum figured by Guex (1995; his plates 3-4 and 6, and Figs. 1 and 10; incl. the holotype and paratypes from bed Z-7). Psiloceras pacificum also commonly have weak to moderately strong ribbing. It may instead be identified as $P$. tilmanni and thus suggest an overlap in range of those two species as is also indicated in correlation schemes (e.g. Hillebrandt and Krystyn, 2009; Hillebrandt et al., 2013; Hillebrandt and Kment, 2015). In any case both taxa indicate the $P$. tilmanni Zone. The smooth, relatively involute Rødby-1 specimen from $556.9 \mathrm{~m}$ also resembles specimens referred to $P$. ex. gr. tilmanni from the Austrian Alps, particular the small specimen 70,237/58 which has whorl height slightly larger, close to equal, than the umbilical diameter and a u/D-ratio of 0.34 .

\subsubsection{Specimen MGUH31588 (depth $556.3 \mathrm{~m}$ ): ?Nevadaphyllites sp.}

The small, smooth specimen is from a level stratigraphically close to the specimen described above (only $0.6 \mathrm{~m}$ apart), which may suggest a close taxonomical relation between the two. However, the specimen from $556.3 \mathrm{~m}$ is markedly more involute than the one from $556.9 \mathrm{~m}$. It is also markedly more involute than all other smooth Psiloceras, as well as all Neophyllites. The closest resemblance to the $556.3 \mathrm{~m}$ specimen is again found in material from the ammonite succession described from the New York Canyon-section (Guex, 1980, 1995), including the likewise involute and smooth Nevadaphyllites compressus. That species has a range from Bed Z-5-Z-14 in the New York Canyon-section, thus overlapping with the range of $P$. pacificum (Beds Z-5-Z-9) (Guex, 1980 ) i.e. including the Bed Z-7 with the possible $P$. tilmanni as discussed above. However, considering the biogeographical distribution of Nevadaphyllites, so far only described from North America, the Rødby1 ammonite is here only tentatively assigned to that genus.

\subsubsection{Chronostratigraphic implications of the Rødby-1 ammonites}

The psiloceratids in Rødby-1 (556.9-556.3 m) are considered to represent Psiloceras tilmanni and ?Nevadaphyllites, and thus represent a somewhat younger level than the $P$. spelae horizon and most likely somewhat older than P. planorbis Zone (Fig. 3). Hence, the psiloceratid interval in Rødby- 1 probably represents a level within the middle $P$. tilmanni Zone (Hillebrandt and Krystyn, 2009) (Fig. 3).

\subsection{Mariental}

The Mariental core was drilled in 2002 by the Geological Survey of Lower Saxony (now: State Authority for Mining, Energy and Geology, LBEG) (Heunisch et al., 2010). The drill site was situated about $5 \mathrm{~km}$ north of Helmstedt (eastern Lower Saxony) and 900 m east of the former Cistercian monastery Mariental. The 129-m-long core comprises Middle Rhaetian to Lower Jurassic (Hettangian) sediments deposited in fluvio-lacustrine to shallow marine settings. The lowermost $12.65 \mathrm{~m}$ of the cored succession belongs to the Contorta Beds of the Exter Formation and 


\section{Mariental \\ Germany \\ Lithostratigraphy}
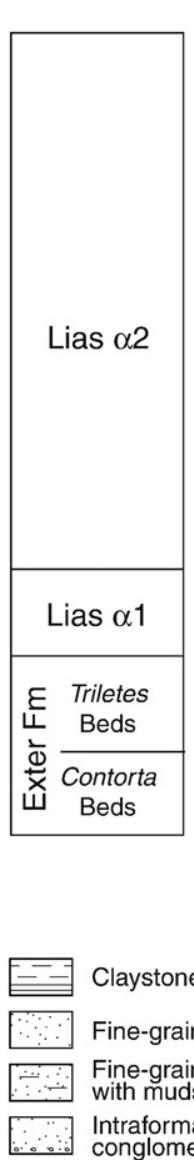

Claystone

Fine-grained sandstone

Fine-grained sandstone with mudstone drapes Intraformationa conglomerate

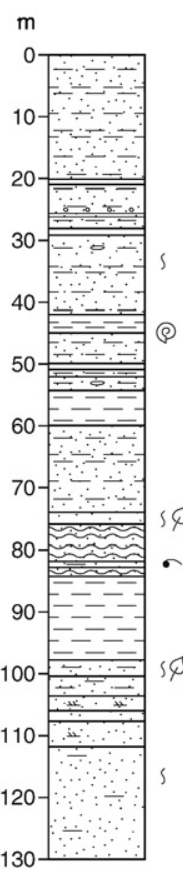

C-isotopes
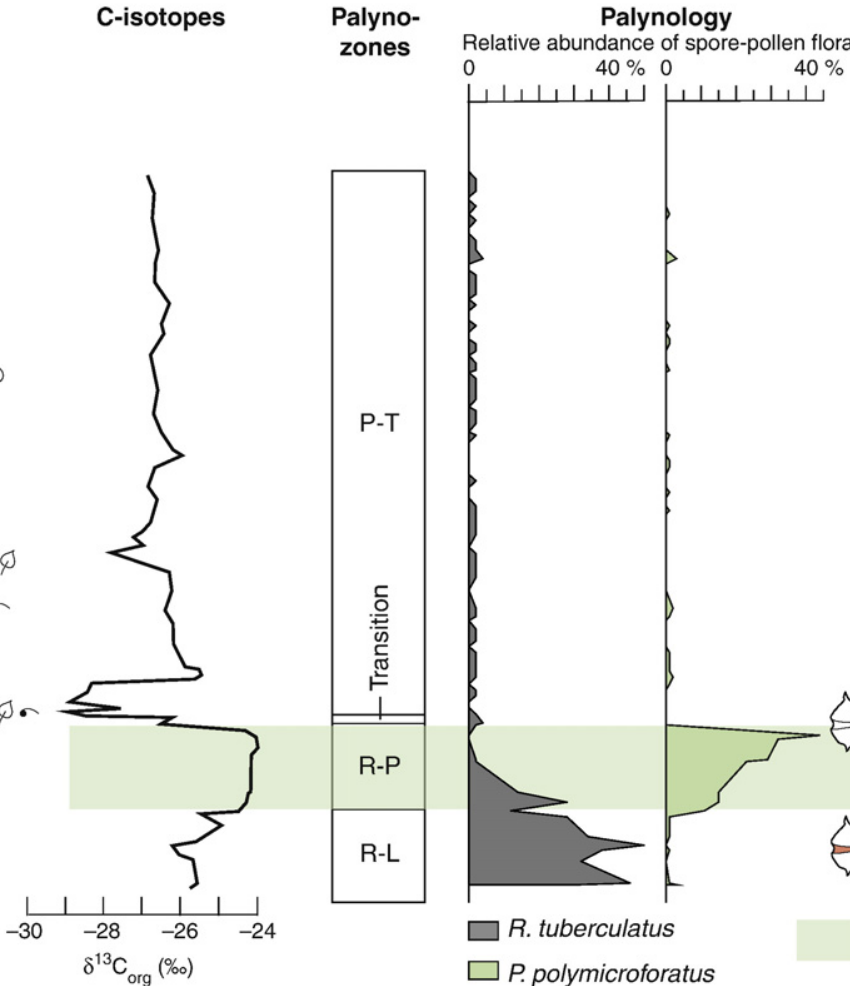

Events
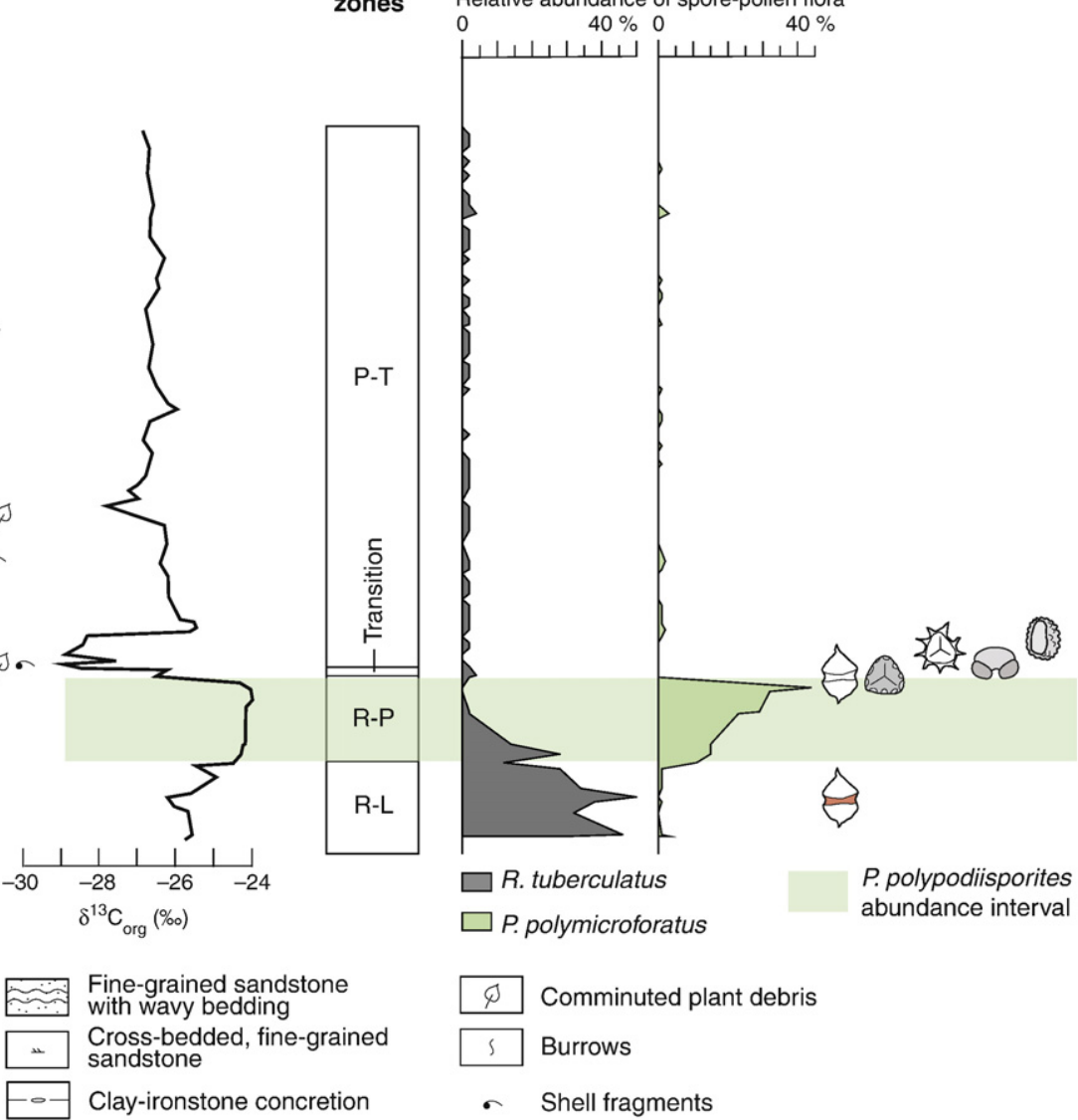

$\varnothing$ Comminuted plant debris

Burrows

- Shell fragments

(P) Ammonites or fragments

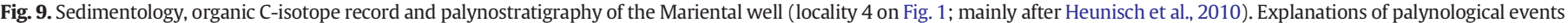
are shown on Fig. 4. R-L = Rhaetipollis-Limbosporites Zone, R-P = Ricciisporites-Polypodiisporites Zone, P-T = Pinuspollenites-Trachysporites Zone.

consist of alternate flaser beddings of fine sandstones and mudstones (Fig. 9). Heunisch et al. (2010) assigned this interval to the Middle Rhaetian Rhaetipollis-Limbosporites (R-L) Zone originally described by Lund (1977). At $116.35 \mathrm{~m}$ it is discordantly followed by $15.5 \mathrm{~m}$ of irregular alternate grey and greenish-grey mudstones and fine-grained sandstones which belong to the Triletes Beds of the Exter Formation. The interval from 115.20-102.95 m was assigned to Lund's (1977) RicciisporitesPolypodiisporites (R-P) Zone (Fig. 9). However, whereas R. tuberculatus was dominant in the R-LZone, it decreases upwards in abundance within the R-P Zone. Polypodiisporites polymicroforatus increases markedly in abundance at the base of the zone and continues to increase towards the top of the zone where it drops and becomes very rare (Fig. 9). This sharp drop may reflect a sequence boundary. The assemblages from 101.25-100.95 $\mathrm{m}$ were assigned to the Transition zone (Heunisch et al., 2010). Above a $1 \mathrm{~m}$ transitional interval of sand- and mudstones, the Hettangian succession starts with a $1 \mathrm{~m}$ thick dark grey mudstone. The succeeding assemblages from $99.5-11.5 \mathrm{~m}$ were placed in the Pinuspollenites-Trachysporites (P-T) Zone. The Lias $\alpha 1$ and the lower part of the Lias $\alpha 2$ up to the base of the Angulata-sandstone (named after the first occurrence of the ammonite Schlotheimia angulata) consist of interbedded mud- and sandstone. Partly fragmented plant remains and shell hashes are present in this unit that is generally poor in macrofossil remains. Heunisch et al. (2010) indicated the presence of ammonites at $44.70-44.60 \mathrm{~m}$, but macrofossils from Mariental have not been described.

\subsection{Schandelah}

The Schandelah core drilling was performed in 2008 near the German city of Braunschweig, and resulted in $338 \mathrm{~m}$ of continuously cored Rhaetian to Toarcian strata. The Rhaetian succession (338.00$318.60 \mathrm{~m}$, depth in meters below surface) at Schandelah can be subdivided into a lower and upper part. The lowermost $3.20 \mathrm{~m}$ (338.00-334.80 m) belong to the Lower Rhaetian Arnstadt Formation. It contains brown, grey, and green claystones with siderite concretions and shows an increase in sand contents towards its top. The presence of dinoflagellate cysts, notably Lunnomidinium, suggests a predominantly shallow marine environment. The overlying unit (334.80-332.00 m) belongs to the Exter Formation and is characterized by sharp-based, medium-grained, current-rippled sandstones with thin muddy partings and abundant plant material and charcoal. The thickest part of the Rhaetian succession at Schandelah is formed by the Triletes Beds (332.00$318.60 \mathrm{~m}$ ). This unit consists of fine-grained light to dark grey sandand siltstones. Liquefaction horizons interpreted as seismites are common in this interval and include flame and ball-and-pillow structures; they are well developed at $330.90 \mathrm{~m}, 326.50 \mathrm{~m}, 324.00 \mathrm{~m}$ and $322.10 \mathrm{~m}$ (Lindström et al., 2015). The Triletes Beds are capped by a very sharp, irregular surface at $318.60 \mathrm{~m}$ that marks the base of the distinctly different facies of the Psilonoten Sandstone (318.60-317.90 m). Muddy bioturbated sandstones dominate in the lower part with better laminated sandstone and interbedded shale facies in the upper part. 


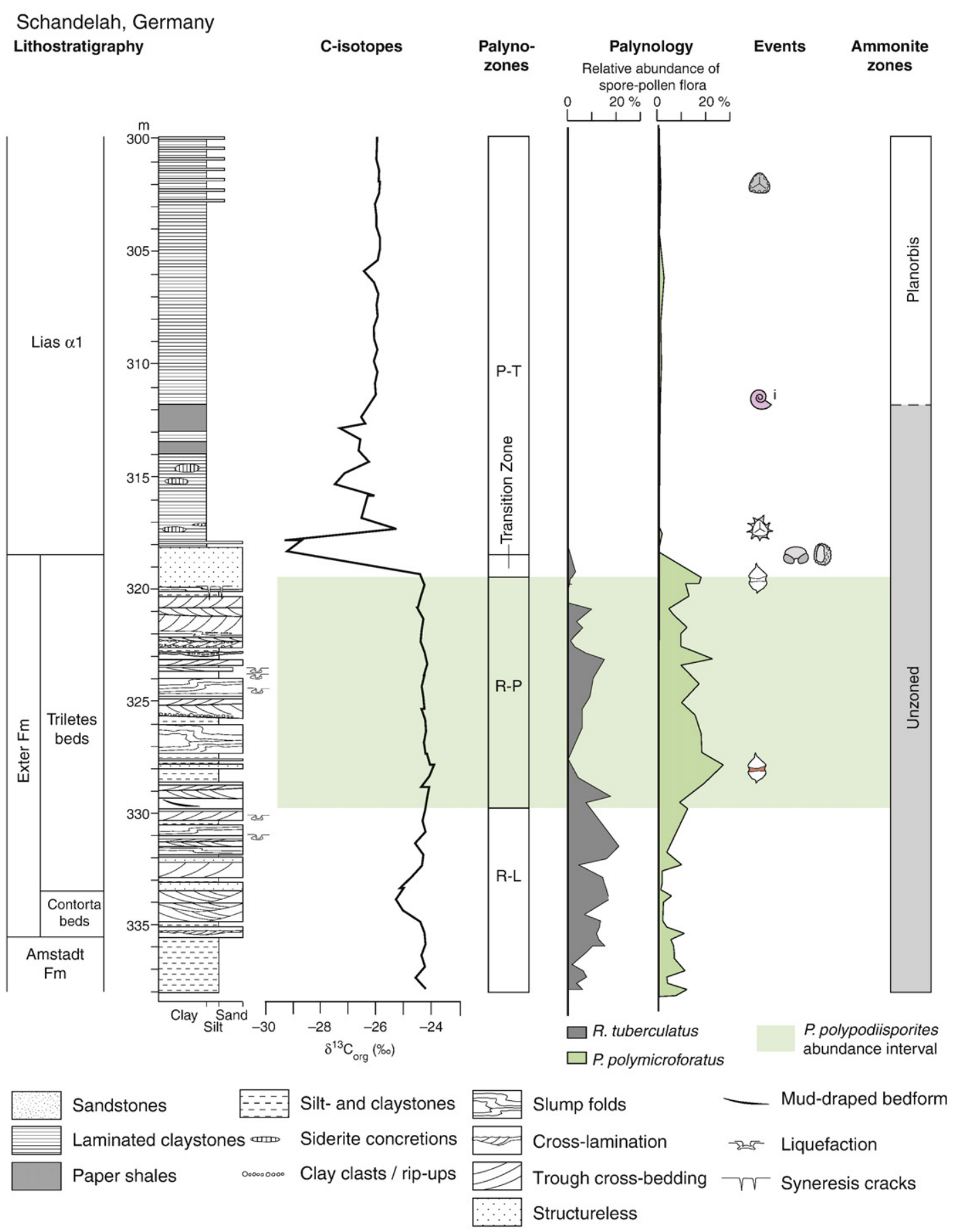

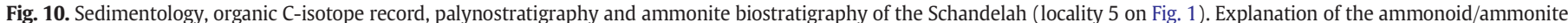

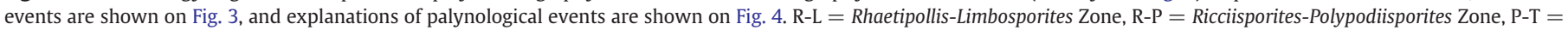
Pinuspollenites-Trachysporites Zone.

This indicates a more open marine influence than seen in the Rhaetian strata below. The basal part of the Hettangian Lias $\alpha$ is composed of laminated shales. Upwards there is an increase in the number of sandstone interbeds.

The LCO of Rhaetogonyaulax rhaetica is in the lower part of the Ricciisporites-Polypodiisporites Zone, while its LO is at the top of the zone. In the R-P Zone, Polypodiisporites polymicroforatus generally exceeds Ricciisporites tuberculatus in abundance. Although $P$. polymicroforatus is also common in the preceding R-L Zone, it is more consistently abundant within the R-P Zone and drops markedly in abundance above this zone (Fig. 10). The FO of Cerebropollenites thiergartii is registered at the same level as the FCO of Pinuspollenites minimus within an interval marked by a sharp negative excursion in the $\delta^{13} \mathrm{C}_{\text {org }}$-record (Fig. 10). The FCO of Kraeuselisporites reissingerii is recorded less than a meter above. A psiloceratid ammonite assigned to Psiloceras sp./ ?Neophyllites sp. (C. Meister, pers. comm. to B.v.d.S.), which probably indicates the lower Planorbis Zone, occurs a little higher in the Lias $\alpha 1$ (Fig. 10).

\subsection{Mingolsheim}

The Mingolsheim core was drilled in 1968 in the vicinity of Bad Mingolsheim (Baden-Württemberg) and is currently stored at the Geological Institute of the University of Heidelberg. The entire core spans 


\section{Mingolsheim Germany Stratigraphy}

Palynol-
zones
C-isotopes

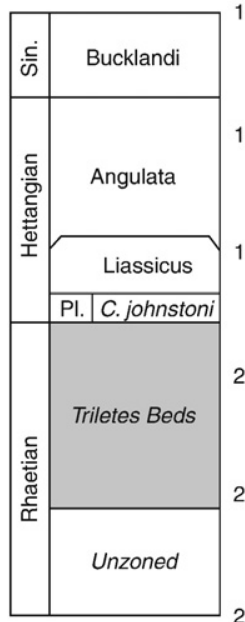

Limestone

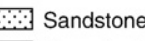

$\square$ Organic rich shale

Organic poor claystone

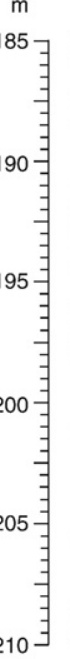

$10 \exists$

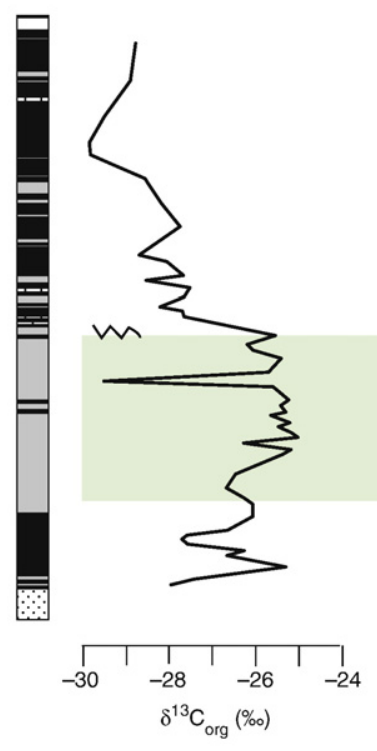

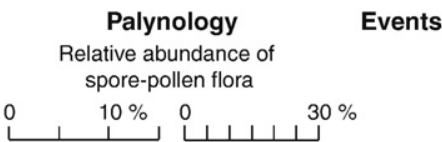

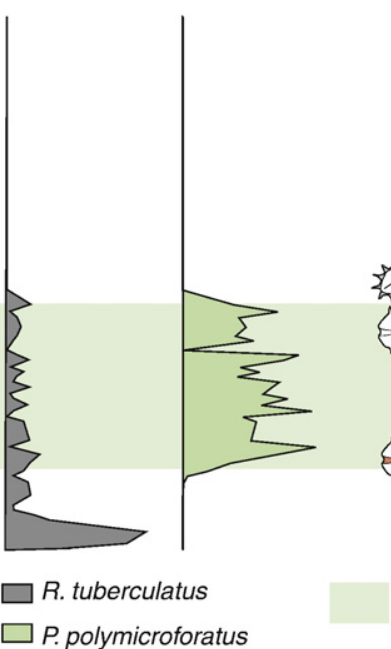

P. polypodiisporites abundance interval

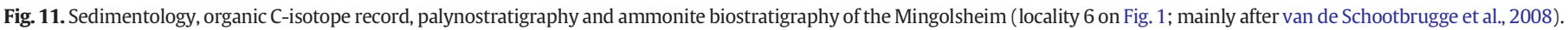
Explanation of the ammonoid/ammonite events are shown on Fig. 3, and explanations of palynological events are shown on Fig. 4.

227 m of Upper Triassic (Rhaetian) to Lower Jurassic (Toarcian) fluviolacustrine to shallow marine sediments. The investigated interval (210$186 \mathrm{~m}$; Fig. 11) consists of middle Rhaetian fluvial sandstones with plant remains that are overlain by the organic-matter rich Rhaetavicula contorta beds, named after a characteristic Late Triassic bivalve. The Contorta beds are overlain by the latest Rhaetian Triletes Beds, a 7.6m-thick, laminated, carbonate and organic matter poor claystone that lacks macrofossils, except for some minor shell fragments (Fig. 11). The palynoflora from the Triletes Beds is assigned to the R-P Zone, although Ricciisporites tuberculatus is not particularly abundant. Polypodiisporites polymicroforatus, on the other hand, occurs in high abundance within these beds and is virtually restricted to this zone (Fig. 11). During the R-P Zone the C-isotope values are more enriched. A single sharp negative peak in the upper part of the zone corresponds to a temporary mass occurrence of conifer pollen (van de Schootbrugge et al., 2008). There is probably a hiatus at the top of the Triletes Beds as these are sharply overlain by the Psilonoten Limestone; a highly condensed, phosphatic and bioclastic limestone containing Jurassic psiloceratid ammonites of the middle Hettangian Caloceras johnstoni Subzone of the Planorbis Zone (Bloos, 1999a) (Fig. 11). The remainder of the Hettangian and basal Sinemurian consists of alternating limestones and shales, with some beds of the latter qualifying as black shales (TOC in excess of 3\%; Quan et al., 2008). The Hettangian part of the Mingolsheim $\mathrm{C}_{\text {org }}$-isotope record exhibits generally negative values (Fig. 11).

\section{Correlations and discussion}

\subsection{Integrated palynology and ammonite biostratigraphy}

The combined palynological and ammonite stratigraphic correlation between NW Europe and Kuhjoch is shown in Fig. 12. Although ammonites have only been recorded at five of the reviewed localities; Kuhjoch, Mingolsheim, Schandelah, Rødby-1 and St. Audrie's Bay, they help to constrain the succession of palynological events.
From Figs. 4-7, 9-11 it is evident that an abundance of Polypodiisporites polymicroforatus characterizes a specific interval at all localities. This interval corresponds to the main palynofloral extinction interval (van de Schootbrugge et al., 2009; Lindström et al., 2012; Lindström, 2016) (Fig. 12). In contrast, the abundance and distribution of the enigmatic gymnosperm pollen tetrad Ricciisporites tuberculatus varies between localities (Figs. 4-7, 9-11). The variation in temporal distribution and abundance of $R$. tuberculatus is particularly striking at Kuhjoch and other Eiberg Basin sections (Kürschner et al., 2007; Bonis et al., 2009; Hillebrandt et al., 2013), where this taxon becomes more abundant upsection (Fig. 4). At all other localities it decreases markedly in abundance during or at the top of the P. polymicroforatus abundance interval and disappears in the lowermost Hettangian. As noted by Lindström (2016) this may suggest that the Eiberg Basin was as a refugium for this taxon after the end-Triassic event.

The LCO of Rhaetogonyaulax rhaetica occurs either just before (Stenlille and Mariental) or during (St. Audrie's Bay, Rødby, Schandelah and Kuhjoch) the P. polymicroforatus abundance interval. At Kuhjoch, the $P$. polymicroforatus abundance interval, which encompasses the Schattwald beds, occurs after the LO of Choristoceras marshi. Thus, both the $P$. polymicroforatus abundance interval and the LCO of $R$. rhaetica occur after the LO of the Triassic ammonoid Choristoceras marshi. This means, that the Schattwald beds at Kuhjoch correlate with the grey siltstone interval in the Stenlille succession, the Cotham Member in the UK, and the Triletes beds in the North German Basin (Fig. 12).

From Fig. 12 it is evident that the P. polymicroforatus abundance interval precedes the $\mathrm{FCO} / \mathrm{FOs}$ of Kraeuselisporites reissingerii, Ischyosporites variegatus, and Pinuspollenites minimus (Fig. 12). However, the local relation of these three events is most likely affected by the regression-transgression couplet which resulted in highly condensed or partially missing strata in many sections (Hallam, 1981; Hallam and Wignall, 1999). At St. Audrie's Bay, this resulted in a regression surface with mud-cracks signaling a hiatus within the uppermost Cotham Member (Hallam and Wignall, 1999; Hesselbo et al., 2004). In Mariental, Schandelah and Mingolsheim, the "Transition zone" strata 


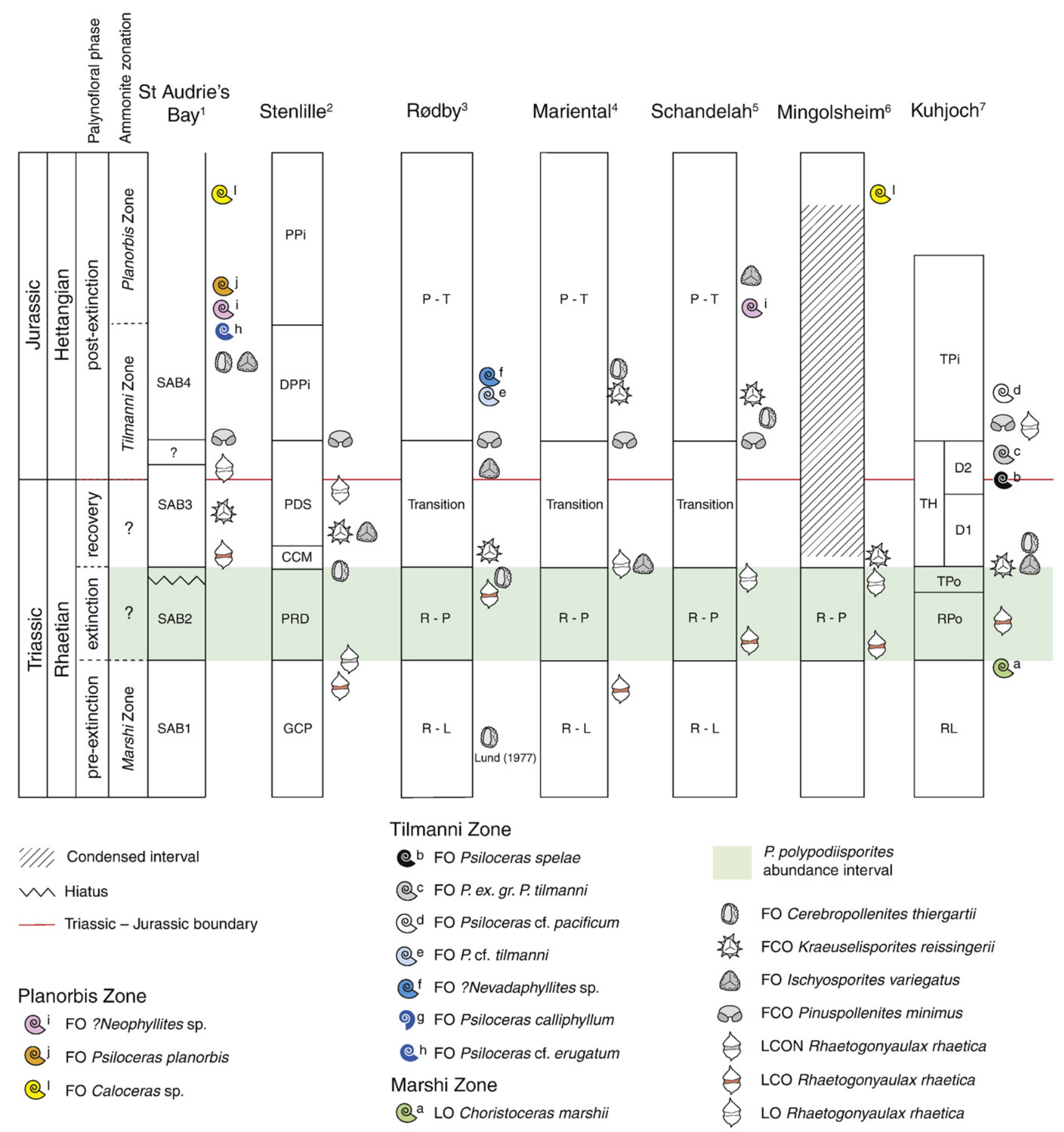

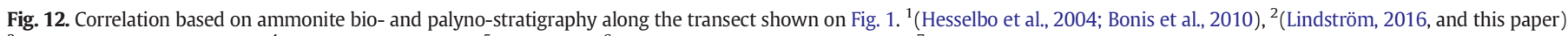

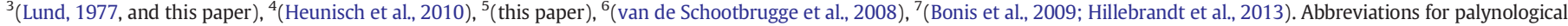
zones are explained on Figs. 4-11, except TPo = Trachysporites-Porcellispora zone.

are condensed to various degrees (or partially missing), comprising less than $2 \mathrm{~m}$ in thickness in all three wells, while in the Rødby- 1 well, equivalent strata comprise a little more than $6 \mathrm{~m}$. This may explain the out-of-sync FCO/FOs of $K$. reissingerii, I. variegatus and $P$. minimus in Mariental, Schandelah and Mingolsheim. In addition, it is evident from Fig. 12 that the FO of Cerebropollenites thiergartii varies between the different localities, suggesting it may not be a reliable accessory marker for the TJB. The discrepancies in $\mathrm{FO}$ of $C$. thiergartii may also be an effect of the regression-transgression couplet, but as noted by already by Lund (1977) early members of $C$. thiergartii can be difficult to separate from other taxa. In particular, Lund (1977) notices that specimens of Chasmatosporites apertus with an uneven tectum can be difficult to distinguish from $C$. thiergartii, and that this distinction is less clear in the Middle Rhaetian.

The P. polymicroforatus abundance interval precedes the FO of Psiloceras spelae at Kuhjoch, clearly placing this interval in the late Rhaetian. Because the FCO of Pinuspollenites minimus succeeds the FOs of both $P$. spelae and $P$. ex gr. tilmanni, this event is clearly early Hettangian in age and should be placed within the lower part of the Tilmanni Zone. By correlating the FCO of $P$. minimus at all localities, it becomes clear that the preceding Transition zone and equivalent zones straddle the TJB. This further indicates that the upper Transition zone and the lower P$\mathrm{T}$ Zone, and equivalents elsewhere correlate with the Tilmanni Zone (Fig. 12). The two re-examined ammonites from the Rødby-1 well 
may represent the hitherto oldest Jurassic ammonites recovered north of the Northern Calcareous Alps (Figs. 3 and 12).

\subsection{Implications for the TJB organic $C_{\text {org-isotope stratigraphy }}$}

The correlation of the ammonite zones and the palynology presented herein affects the correlation of the NW European $\mathrm{C}_{\text {org-isotope re- }}$ cords to that of Kuhjoch in the Northern Calcareous Alps (Fig. 13). Due to the restricted temporal distribution of the P. polymicroforatus abundance interval at all localities, it serves as an excellent marker for correlating these TJB successions. Here, the onset of the $P$. polymicroforatus abundance interval is used as base line, rather than its top, as the latter is often associated with a hiatus or strongly condensed strata (Fig. 13). Because we propose a revised correlation of $\mathrm{C}_{\text {org }}$-isotope records and because the names assigned to the three previously defined CIEs are poorly significant in terms of stratigraphy, we propose here to rename these CIEs according to significant ammonite markers. In all of the NW European localities, the onset of the P. polymicroforatus abundance interval is preceded by a negative CIE which, although it is generally of a small amplitude, can be correlated with the very sharp negative $\mathrm{C}_{\text {org }}$-excursion at the top of the T-bed of the Kössen Formation at Kuhjoch, associated with the LO of Choristoceras marshi (Fig. 13). At Kuhjoch this level marks the onset of the extinction (Hillebrandt et al., 2013). This CIE, here referred to as the Marshi CIE, is succeeded by a very sharp shift to less depleted $\delta^{13} \mathrm{C}_{\text {org }}$-values (Fig. 13). This contrasts to the traditional correlation where the pronounced Marshi CIE at Kuhjoch has been correlated with the sharp "initial CIE" (herein the Spelae CIE) at St. Audrie's Bay (Fig. 1), but is strongly supported by the ammonite bio- and palyno-stratigraphy (Figs. 13-14). The traditional correlation partly relied on the FO of Cerebropollenites thiergartii and the LO of Triassic conodonts. As shown in this paper (Fig. 13), and also discussed by others (Heunisch et al., 2010; Lindström, 2016), Cerebropollenites thiergartii can be quite difficult to recognize and is often very rare when it first appears in the stratigraphical record. In addition, Hallam (1991) questioned the LO of conodonts within the Langport Member at St. Audrie's Bay, and suggested that they might be reworked.

The thickness of the strata deposited between the Marshi CIE and the base of the P. polymicroforatus abundance interval is ca. 3-3.5 $\mathrm{m}$ at all localities except at Kuhjoch where this interval is highly condensed, encompassing 20-30 cm in thickness (Fig. 13). The high-resolution palynological record of Stenlille shows a marked decline in gymnosperm pollen and dinoflagellate cysts during this interval (Lindström et al., 2012). A similar pattern is evident in Mariental and Mingolsheim (van de Schootbrugge et al., 2009; Heunisch et al., 2010). At Kuhjoch and St. Audrie's Bay, the P. polymicroforatus abundance interval coincides with the main marine extinction phase (Mander et al., 2008; McRoberts et al., 2012; Hillebrandt et al., 2013). In the Stenlille record, this interval is virtually devoid of trace fossils and bivalves (Lindström et al., 2012). The $P$. polymicroforatus abundance interval is associated with more positive $\delta^{13} \mathrm{C}_{\text {org }}$ values, and encompasses the so-called event beds (grey siltstone interval, Triletes beds, Cotham Member) of Lindström et al. (2012), which correlate with the Schattwald beds at Kuhjoch (Fig. 13). The supraregional seismites recorded by Lindström et al. (2015) are mainly concentrated in this interval. These event beds further represent the regressive event described by Hallam (1981). They have been interpreted to have formed as a consequence of terrestrial acidification, with subsequent deforestation, enhanced weathering and erosion and increased transport of sediments into the basins (van de Schootbrugge et al., 2009; Lindström et al., 2012, 2015). As many of the pollen taxa decrease markedly and also disappear within or soon after these event beds, the changes in the terrestrial palynoflora cannot merely be the result of the regression. Likewise, in many areas, spores continue to be abundant after the event while P. polymicroforatus decreases significantly and disappears shortly after (see also discussion in Lindström, 2016).
The transgression (MFS 8 in Stenlille and Rødby-1; Figs. 6 and 7) that followed the $P$. polymicroforatus abundance interval has greatly influenced deposition and preservation of strata in many areas, and this also affects the signature of the $\mathrm{C}_{\text {org }}$-isotope record (Fig. 13). The correlation presented herein suggests that the "initial CIE" at St. Audrie's Bay corresponds to the negative $\delta^{13} \mathrm{C}_{\text {org }}$-values recorded in the topmost Schattwald beds (above the hiatus) and in the grey Tiefengraben Member (up to ca. $8 \mathrm{~m}$; Fig. 13). This places the FO of psiloceratid ammonites, specifically $P$. spelae, within this CIE, which is therefore herein referred to as the Spelae CIE (Fig. 13). It should be noted that the FO of P. spelae is within the upper part of the CIE. At Kuhjoch the Spelae CIE encompasses ca. $6 \mathrm{~m}$ of strata before the $\delta^{13} \mathrm{C}_{\text {org }}$ values again become less depleted. At St. Audrie's Bay, Rødby and Stenlille, the Spelae CIE encompasses between less than $2 \mathrm{~m}$ to ca. $4 \mathrm{~m}$ of strata, while at Mariental, Schandelah and Mingolsheim this interval is probably highly condensed or partly missing (Fig. 13). The "main CIE" at St. Audrie's Bay can clearly be recognized in all localities as a return to lower $\delta^{13} \mathrm{C}_{\text {org }}$ values that persist upwards during the Planorbis Zone. As this negative excursion occurs within the upper Tilmanni Zone, it is herein suggested to be referred to as the top-Tilmanni CIE (Fig. 13). At the time of this CIE the terrestrial palynoflora appears fairly stabilized, but the marine ecosystem is far from recovered (Lindström et al., 2012).

The new correlation presented herein also has consequences for the interpretation of prasinophyte acmes recorded in several TJB successions (van de Schootbrugge et al., 2007; Kürschner et al., 2007; Götz et al., 2009; Bonis et al., 2009; Ruhl et al., 2010a; Ibarra et al., 2016). It is clear from the palynostratigraphic records of these localities that there are several episodes of prasinophyte acmes throughout the Rhaetian and Early Jurassic. At Kuhjoch, a high abundance of prasinophycean algae, initially Cymatiosphaera polypartita followed by Tasmanites spp., that coincides with the upper part of the Marshi CIE and continues during the less depleted C-isotope interval in the Schattwald beds (Bonis et al., 2009). This was interpreted as reflecting nutrient rich surface waters of low salinity and was found to occur in sections all over the Eiberg Basin (Ruhl et al., 2010a). A similar increase in abundance of the same taxon was recorded immediately above the Marshi CIE in the Westbury Formation at St. Audrie's Bay (Bonis et al., 2010). As these prasinophycean algal blooms occur during the onset of the regressive phase, and may therefore be a combined response to more proximal settings in combination with increased freshwater influence. A marked shift from a dinoflagellate cyst-dominated phytoplankton flora, to one dominated by other prasinophycean algal taxa (primarily Leiosphaeridia spp.) was recorded in the uppermost Cotham Member to lower Blue Lias Formation, i.e. coinciding with the Spelae CIE and the succeeding less depleted C-isotope interval (van de Schootbrugge et al., 2007; Bonis et al., 2010). At the same stratigraphical level in Kuhjoch, i.e. from the Spelae CIE and during the succeeding less depleted C-isotope interval in the grey Tiefengraben Member, a corresponding increase in the abundance of Leiosphaeridia spp. was recorded by Bonis et al. (2009). Richoz et al. (2012) interpreted this shift in phytoplankton dominance as a consequence of presence of sulphidic waters in parts of the photic zone, leading to ammonium-enrichment in the surface waters which favoured proliferation of green algae.

\subsection{Correlation with radiometrically dated TJB successions and CAMP basalts}

The ammonite and $\mathrm{C}_{\mathrm{org}}$-stratigraphy of the New York Canyon section in Nevada (U.S.A.) and the ammonite succession of the Pucara Basin in Peru are both associated with volcanic ash beds which have been dated using $\mathrm{U} / \mathrm{Pb}$ geochronology of zircons (Schoene et al., 2010; Wotzlaw et al., 2014). Unfortunately, none of these sections have yielded identifiable palynomorphs. In both these successions, the extinction interval was placed between the LO of Choristoceras crickmayi and the FO of Psiloceras spelae (Schoene et al., 2010). Because P. spelae occurs together with P. tilmanni in Nevada, this ammonite level is 


\section{St Audrie's Bay, England $^{1}$}

\author{
Stenlille \\ Denmark $^{2}$
}

Rødby-1

Denmark $^{3}$
Mariental

Germany ${ }^{4}$

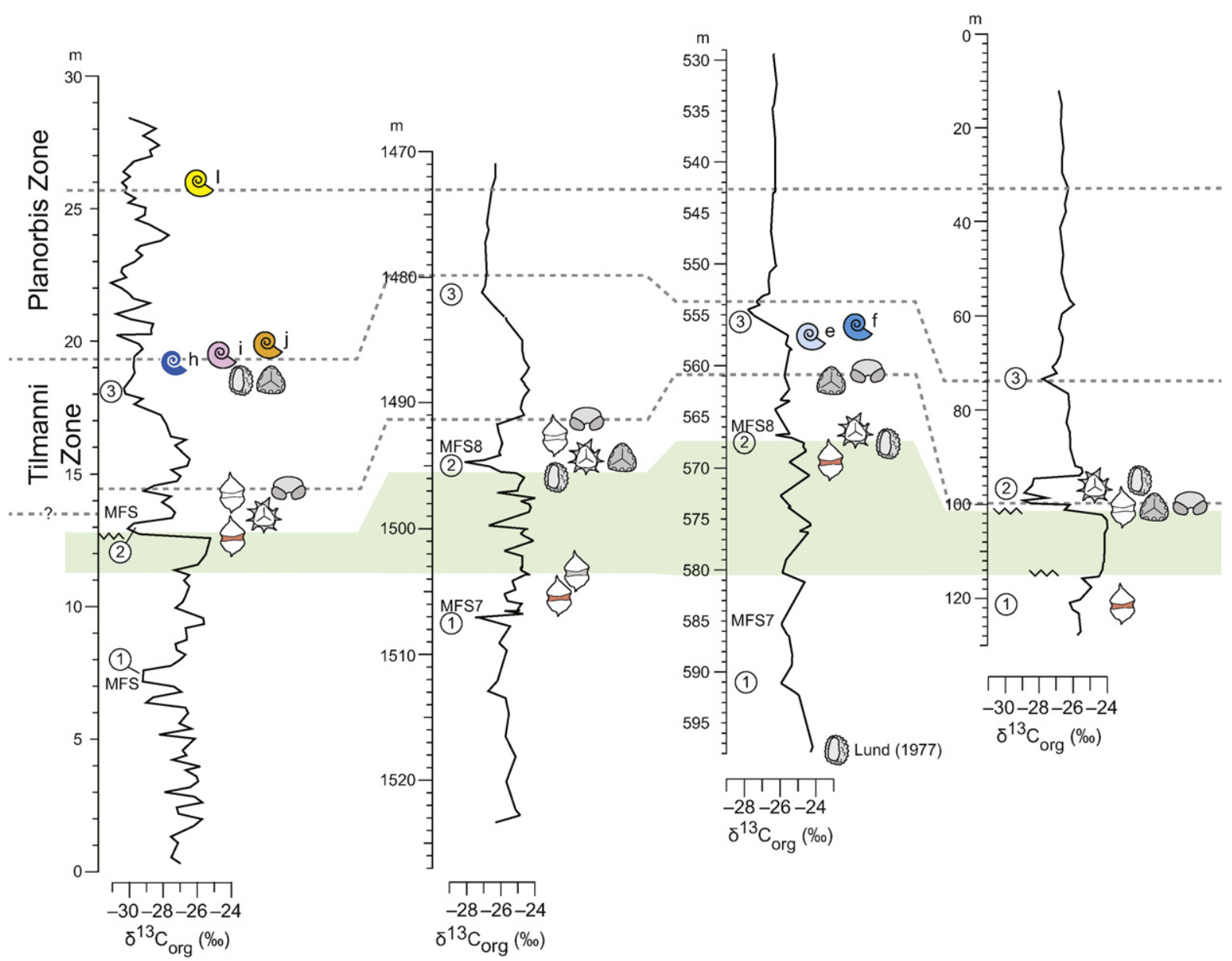

Fig. 13. Correlation based on ammonite bio- and palyno-stratigraphy, including the $\delta^{13} C_{\text {org }}$ records for each locality, along the transect shown on Fig. 1 .

considered to be slightly younger than the FO of $P$. spelae at Kuhjoch (Hillebrandt and Kment, 2015). Fig. 14 shows the proposed new correlation including the radiometrically dated New York Canyon and Pucara Basin successions. The LO of C. crickmayi is in the Pucara Basin succeeded by two volcanic ash beds located within the extinction interval (the white field on Fig. 14), and these were dated to $201.51 \pm 0.15 \mathrm{Ma}$ and $201.39 \pm 0.14 \mathrm{Ma}$ (Fig. 15; Wotzlaw et al., 2014). The FO of Psiloceras spelae is at New York Canyon succeeded by one ash bed dated to $201.33 \pm 0.13 \mathrm{Ma}$, and in the Pucara Basin by another one dated to $201.29 \pm 0.16 \mathrm{Ma}$ (Figs. 14-15; Schoene et al., 2010). Based on the two radiometric ages bracketing the FO of $P$. spelae in the Pucara Basin, the calculated age of the TJB is $201.36 \pm 0.17 \mathrm{Ma}$ (Schoene et al., 2010; Wotzlaw et al., 2014).

Blackburn et al. (2013) presented U/Pb zircon ages for a selection of CAMP volcanics. For the North Mountain Basalt (Fundy Basin, Canada), which on its chemical composition and characteristics is assigned to the lower CAMP unit, a mean age of $201.556 \pm 0.031$ Ma was obtained (Blackburn et al., 2013). However, it should be noted that Blackburn et al. (2013) also reported an additional, but slightly younger age of $201.522 \pm 0.064$ Ma for the North Mountain Basalt in their supplementary material. Schoene et al. (2010) reported an even younger age, $201.538 \pm 0.02 \mathrm{Ma}$ for the North Mountain Basalt. The discrepancies between these three very different ages were not discussed by Blackburn et al. (2013). The intermediate CAMP units in Morocco (Amelal sill in the Argana Basin) and eastern North America (Palisades sill in the Newark Basin), where dated as 201.564 $\pm 0.054 \mathrm{Ma}$ and $201.520 \pm 0.034 \mathrm{Ma}$, respectively (Blackburn et al., 2013). Plotting these radiometric ages (including ages for other CAMP units obtained by Blackburn et al., 2013) together with the $\mathrm{U} / \mathrm{Pb}$ ages for the New York Canyon and Pucara Basin ash beds, along with the new correlation presented herein, indicates that both the lower and intermediate CAMP basalts are synchronous to or pre-date the Marshi CIE and the extinction interval (Figs. 14-15).

In addition, the radiometric ages of $201.305 \pm 0.034 \mathrm{Ma}$ and $201.274 \pm 0.032 \mathrm{Ma}$ for the Preakness basalt and the Rossville intrusive, respectively (Blackburn et al., 2013), suggest that this phase of the CAMP volcanism possibly was synchronous to the TJB and the Spelae CIE (Figs. 1 and 15).

4.4. Implications for the age of the pre-CAMP terrestrial successions in Morocco and Eastern North America

Terrestrial palynology from the sedimentary successions below and between CAMP basalts in Morocco and eastern North America has been a subject of controversy over the last decades. Traditionally, the TJB has been placed below the oldest CAMP basalts, i.e. the North Mountain Basalt in the Fundy Basin, the Orange Mountain Basalt in the Newark Basin, and the Lower Unit in the Argana Basin in Morocco (e.g. Fowell and Olsen, 1993; Olsen et al., 2002; Whiteside et al., 2007, 2008). These authors based the position of the TJB on the last occurrences of Enzonalasporites spp., Patinasporites densus and Vallasporites ignacii, and a subsequent increase in pollen assigned to Classopollis spp. Other authors have argued that the last occurrences of Enzonalasporites spp., 

Schandelah Germany ${ }^{5}$
Kuhjoch, Austria $^{7}$

\section{Mingolsheim \\ Germany ${ }^{6}$}

Planorbis Zone

Q) I FO Caloceras sp.

Qk FO Psiloceras naumanni

(Q) j FO Psiloceras planorbis

(9) i FO ?Neophyllites sp.

$P$. polypodiisporites abundance interval

$m$ Hiatus

Tilmanni Zone

h FO Psiloceras cf. erugatum

๑g FO Psiloceras calliphyllum

(Q) f FO ?Nevadaphyllites sp.

(9) FO P. cf. tilmanni

(Q) d FO Psiloceras cf. pacificum

(9) $c$ FO P. ex. gr. P. tilmanni

eb FO Psiloceras spelae

Marshi Zone

(9) a LO Choristoceras marshii

\section{FCO Pinuspollenites minimus \\ 0 FO Cerebropollenites thiergartii \\ FO Ischyosporites variegatus \\ FCO Kraeuselisporites reissingerii}

(1) Marshi CIE

(2) Spelae CIE

(3) top-Tilmanni CIE

Fig. 13 (continued).

P. densus and Vallasporites ignacii instead indicate an early Rhaetian age, or older, following the known last appearance datums in NW Europe of these pollen taxa (Van Veen, 1995; Marzoli et al., 2004, 2008; Cirilli et al., 2009). In addition, several authors have also argued that an increase in fern spores, a spore spike, just below the oldest CAMP basalts would mark the end-Triassic event, similar to the spore spike recorded after the end-Cretaceous mass extinction (Olsen et al., 2002; Whiteside et al., 2010; Vajda et al., 2001). The Polypodiisporites polymicroforatus abundance interval in NW Europe, which is synchronous to the marine extinction interval, is associated with long-term increased abundances of other fern spores in many areas on both hemispheres (Lindström, 2016). The new correlation presented herein shows that the Newark Basin fern spike pre-dates the Polypodiisporites polymicroforatus abundance interval, and hence also the extinction interval. The Newark Basin fern spike reflects a local or regional shift in vegetation, as was suggested by Bonis and Kürschner (2012). However, it is also possible that this this shift in the vegetation was be related to the onset of the CAMP volcanism in Morocco, estimated to be 14,000 years older that the Orange Mountain Basalt (Blackburn et al. 2013). Similarly, a negative shift in $\delta^{13} C_{\text {org }}$ below the lowermost CAMP basalts Morocco and eastern North America, originally correlated with the "initial CIE", i.e. the Spelae CIE, at St. Audrie's
Bay and suggested to mark the end-Triassic extinction (Whiteside et al., 2010; Deenen et al., 2010; Dal Corso et al., 2014), must represent an older fluctuation in the carbon cycle and may correspond to the onset of the Marshi CIE.

\subsection{Implications for the end-Triassic event}

The alternative correlation presented herein has implications on our understanding of the end-Triassic event, and its causes and consequences. First of all, the new correlation indicates that the bulk of the dated CAMP basalts (Blackburn et al., 2013) either pre-date or are synchronous to the Marshi CIE and may therefore be the main trigger of the extinction (Fig. 14). At Kuhjoch, the Marshi CIE has an amplitude of $~ 6 \%$ in the bulk organic record, and its great magnitude has been interpreted to reflect massive input of isotopically light carbon in the form of methane to the atmosphere (Ruhl et al., 2011). At the other NW European records, the Marshi CIE has a lower amplitude, while it seems to be the most pronounced excursion in the New York Canyon record (Fig. 13). The nature of volcanic degassing is dependent on the volcanic process responsible for the release of light carbon as discussed by Jones et al. (2016). If degassing from contact aureoles is involved, the released carbon can 


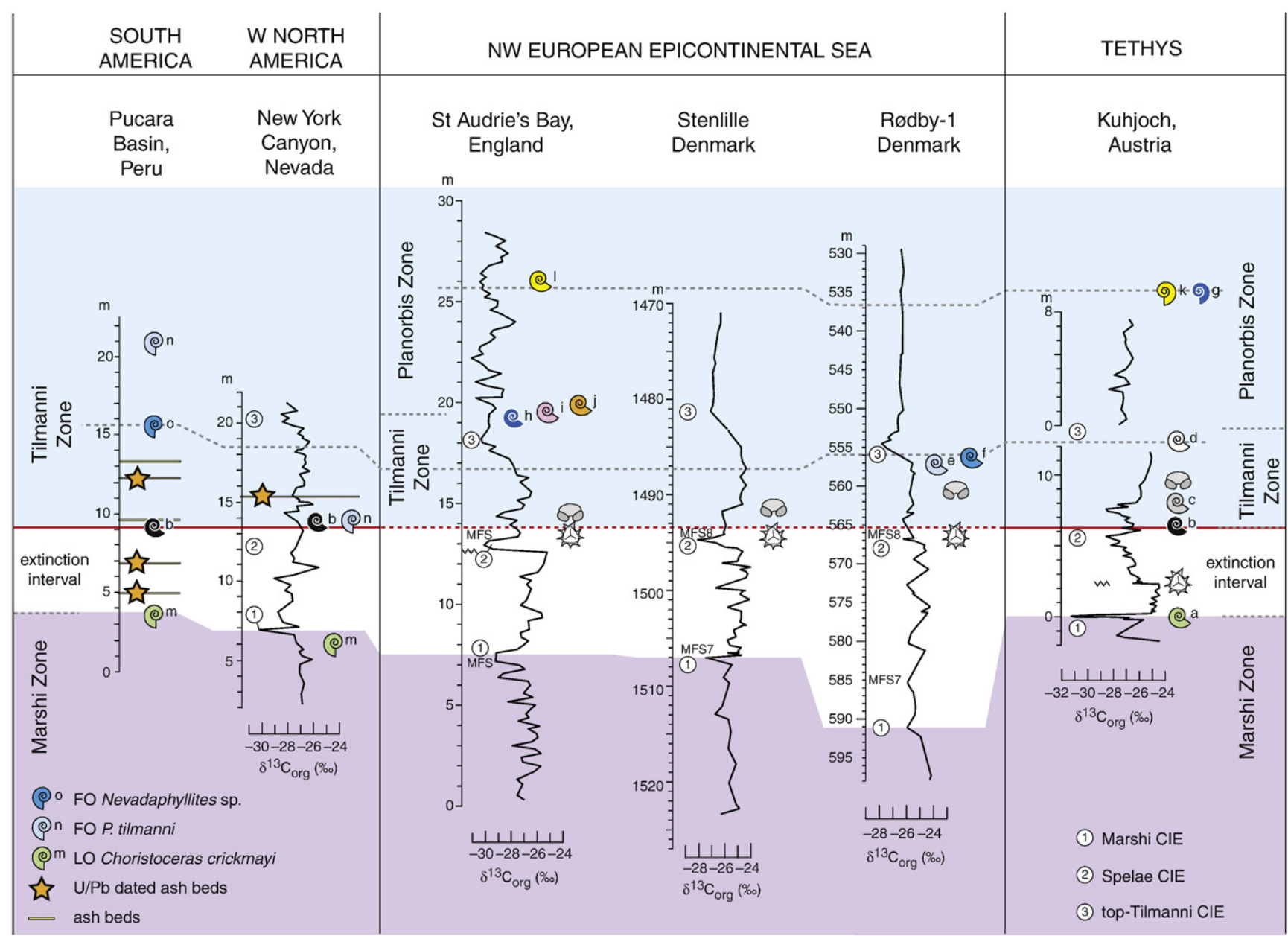

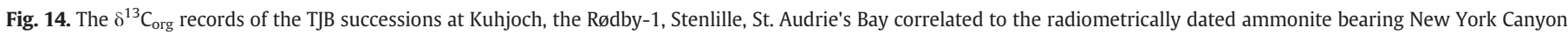

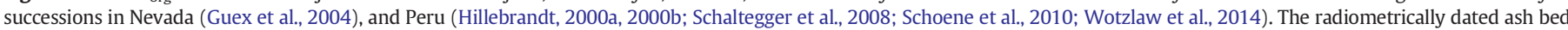

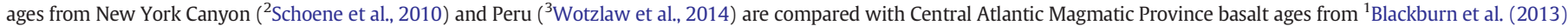
on Fig. 15.

have an isotopic signature that is substantially lower than juvenile $\mathrm{CO}_{2}$ from volcanic emissions (see e.g. Aarnes et al., 2010). In any case, because both the marine and terrestrial ecosystems exhibit demise and/or gradual decline in the abundance of previously prominent taxa after the Marshi $\mathrm{CIE}$, it seems likely that the cause of the CIE triggered the onset of the extinction in both the marine and terrestrial realm.

The Spelae CIE is possibly also linked to an eruptive phase of the CAMP (Fig. 14). It straddles the TJB, and is associated with a transgressive phase which is likely responsible for a slight truncation of most, if not all, of the NW European successions (Fig. 13). At e.g. St. Audrie's Bay and Stenlille the Spelae CIE displays a sharp negative peak, which is not evident at Kuhjoch (Fig. 13). However, considering that the succession containing the Spelae CIE at Kuhjoch appears to be more expanded compared to the other localities, the amplitude from the most positive value preceding the CIE to its most negative peak is within the same range as the others (Fig. 13). The herein presented alternative correlation suggests that the Spelae CIE post-dates the major phase of the extinction (Fig. 13). However, in some areas, like in the UK, it is associated with a post-extinction dead zone for benthic shelly invertebrates and foraminifera, as well as calcareous nannoplankton in the upper Cotham and lower Langport Members (Mander et al., 2008; Clémence et al., 2010). At the same time, the terrestrial ecosystem had begun to recover, although extinctions of lingering taxa were still on-going (Lindström, 2016).

At St. Audrie's Bay and other TJB localities in SW Britain, the Spelae $\mathrm{CIE}$ is succeeded by an interval with more positive $\mathrm{C}$-isotope values in both organic and carbonate material and associated with relatively positive O-isotope values (Korte et al., 2009). This was interpreted as reflecting enhanced carbon burial and subsequent bottom-water cooling (Korte et al., 2009). Currently, it is not clear whether the succeeding top-Tilmanni CIE is synchronous to any CAMP eruptions (Fig. 14). This CIE appears to mark a shift to generally lower $\delta^{13} \mathrm{C}$ values than during the Rhaetian.

\subsection{Timeline for end-Triassic events}

The implications of the herein presented correlation is summarized in a timeline (Fig. 15). The basalts and dykes are categorized stratigraphically and geochemically as: lower, lower/intermediate, intermediate and upper, high-titanium, quartz normative (HTQ); low-titanium, quartz normative (LTQ); high-Fe, and quartz normative (HFQ), after Marzoli et al. (2011) and Blackburn et al. (2013) and references therein.

The timeline commences with the virtual disappearance of pollen assigned to Patinasporites densus/Enzonalasporites spp. in Morocco and eastern North America, followed by the eruption of the oldest CAMP basalts in Morocco and Fundy Basin (Fig. 15). The so far undated lower HTQ CAMP basalt (the Tasguint basalt) in Morocco is estimated to be 3000 years older than the lower-intermediate HTQ North Mountain Basalt in the Fundy Basin, radiometrically dated to $201.566 \mathrm{Ma} \pm$ $0.031 \mathrm{Ma}$. The Tasguint basalt is also regarded to be 14,000 years older 


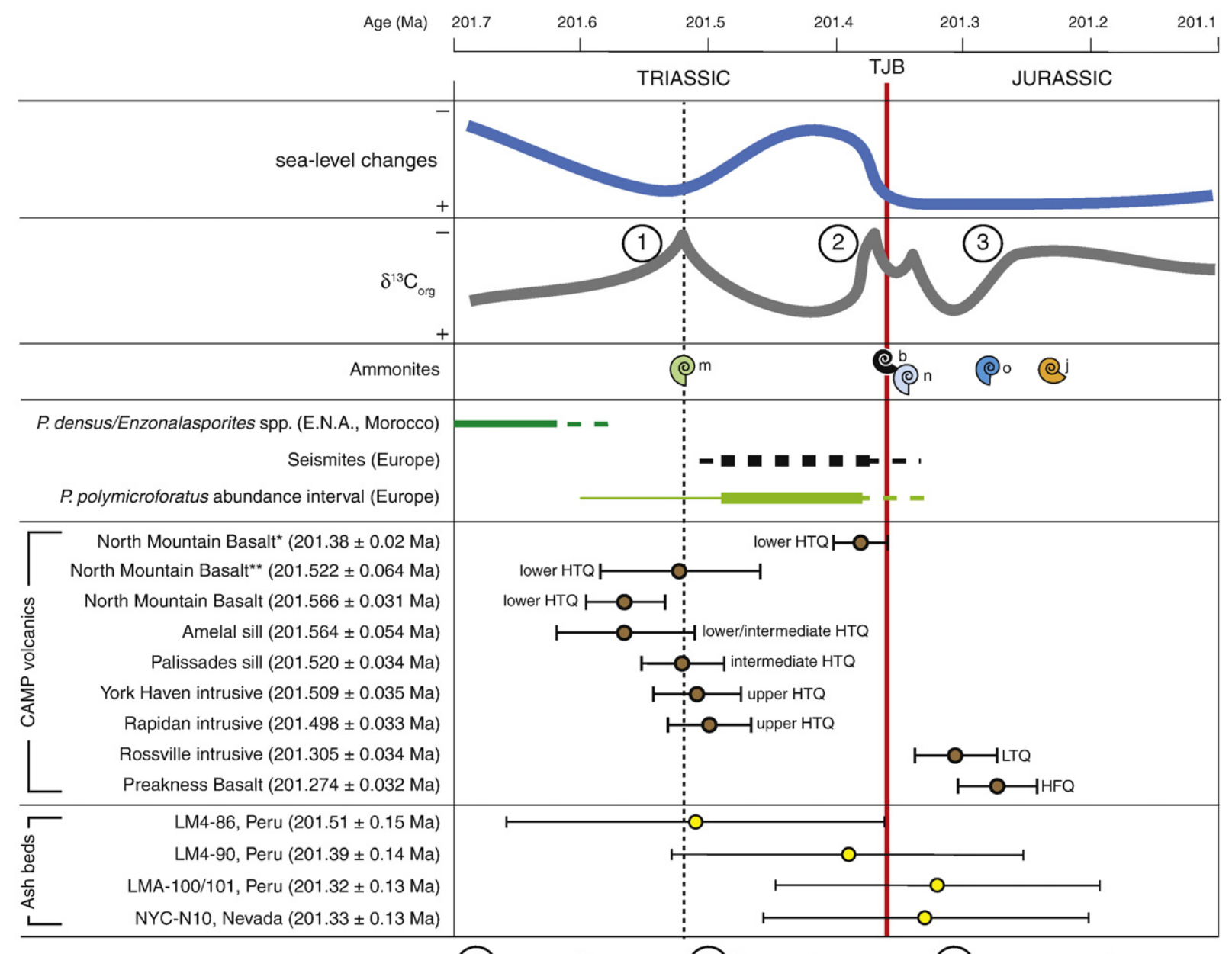

- TJB = Triassic-Jurassic boundary

(1) Marshi CIE

(2) Spelae CIE

(3) top-Tilmanni CIE

Fig. 15. Timeline of events around the end-Triassic mass extinction; synthesis from the new correlation presented in Figs. 12-14. Simplified relative sea-level curve for NW Europe and composite C-isotope curve based on the reviewed records herein. Stratigraphic range for Patinasporites densus/Enzonalasporites spp. in Morocco and eastern North America (E.N.A.) after Fowell and Olsen (1993), Olsen et al. (2002), Whiteside et al. (2007, 2008), Cirilli et al. (2009), Marzoli et al. (2011). CAMP U-Pb ages are from Blackburn et al. (2013), with the exception of the age for the North Mountain Basalt marked with *, which is from Schoene et al. (2010). The North Mountain Basalt age marked with ** is an additional age from Blackburn et al. (2013) provided in their supplementary material.

than the intrusion of the intermediate HTQ Amelal sill (Morocco), radiometrically dated to $201.564 \pm 0.054 \mathrm{Ma}$ (Blackburn et al., 2013).

The next set of events that appear to have coincided in time are: the last occurrences of ammonoids Choristoceras marshi and C. crickmayi, and the onset of the end-Triassic extinction (Guex et al., 2004; Hillebrandt et al., 2013); a perturbation of the carbon cycle, i.e. the Marshi CIE; and intrusion of the intermediate HTQ Palisades sill (Newark Basin) radiometrically dated to $201.520 \pm 0.034 \mathrm{Ma}$ (Blackburn et al., 2013). These events were further coincident with a maximum flooding recorded in NW Europe and in the Northern Calcareous Alps (Hesselbo et al., 2004; Hillebrandt et al., 2013; Lindström et al., 2015).

In Peru, the LO of Choristoceras crickmayi is post-dated by the local/ regional volcanic ash bed LM4-86, radiometrically dated to $201.51 \pm$ $0.15 \mathrm{Ma}$ (Wotzlaw et al., 2014). In eastern North America, CAMP activity continued with the intrusion of the upper HTQ York Haven Diabase (Gettysburg Basin) at 201.509 $\pm 0.035 \mathrm{Ma}$ and Rapidan Sheet (Culpeper Basin) at 201.498 $\pm 0.033 \mathrm{Ma}$ (Blackburn et al., 2013). These events occurred during a global major decline in conifers and other trees, as indicated by the pollen record (van de Schootbrugge et al., 2009; Lindström et al., 2012; Lindström, 2016). At this time deposition of the event beds; i.e. the grey siltstone interval in the Danish Basin, the Triletes beds in the North German Basin and the Schattwald beds in the Northern Calcareous Alps, takes place marking the onset of a major regression in Europe (Hallam and Wignall, 1999).
During the maximum phase of extinction and ecological disturbance, local/regional volcanic activity in Peru caused deposition of ash bed LM4-90 at 201.39 $\pm 0.14 \mathrm{Ma}$. Opportunistic ferns, including the parent plant of $P$. polymicroforatus, proliferated in NW Europe and the Northern Calcareous Alps (van de Schootbrugge et al., 2009; Lindström, 2016). In fact, spore producing plants appear to have been favoured globally, during this time (Lindström, 2016). At the same time Europe was affected by intense repeated seismicity (Lindström et al., 2015). The earthquake activity more or less culminated during the maximum regression, as exemplified by the St. Audrie's Bay record (Simms, 2003, 2007). The organic $\delta^{13} \mathrm{C}$-record generally exhibits less depleted values.

The next set of events commenced with the transgressive event of Hallam (1981) and Hallam and Wignall (1999), and a perturbation of the carbon cycle; the "initial CIE" of Hesselbo et al. (2002), herein referred to as the Spelae CIE. The first appearance of the ammonite Psiloceras spelae within the Spelae CIE marks the Triassic-Jurassic boundary. This was followed by the first occurrence of Psiloceras tilmanni. On land, the recovery of terrestrial vegetation and return of conifers had begun (Lindström, 2016).

Local/regional volcanic activity in Nevada and Peru caused deposition of ash beds LMA-100/101 at 201.32 $\pm 0.13 \mathrm{Ma}$ and NYC-N10 at $201.33 \pm 0.13 \mathrm{Ma}$ (Schoene et al., 2010; Wotzlaw et al., 2014). Positive $\delta^{13} \mathrm{C}$ values may signal enhanced organic carbon burial (van de Schootbrugge et al., 2008; Korte et al., 2009). Intrusion of the LTQ 
Rossville Diabase in eastern North America at $201.305 \pm 0.034 \mathrm{Ma}$ (Blackburn et al., 2013), and the eruption of the HFQ Preakness Basalt $201.274 \pm 0.032 \mathrm{Ma}$ (Blackburn et al., 2013), appears to have coincided in time with the first occurrence of Nevadaphyllites sp. This is succeeded by a shift to more depleted $\delta^{13} \mathrm{C}$ values; the onset of the long-lasting top-Tilmanni CIE. At this level the onset radiation of psiloceratid ammonites, including P. planorbis, commenced.

\section{Conclusions}

A combination of palynostratigraphic events and ammonite stratigraphy applied to the TJB succession at St. Audrie's Bay (UK), Stenlille and Rødby (Denmark), Mariental, Schandelah and Mingolsheim (Germany) and Kuhjoch (Austria) have resulted in a new correlation of the $\delta^{13} C_{\text {org }}$-records and the end-Triassic extinction across NW Europe. This correlation differs primarily from previous attempts, by not correlating the two most negative CIEs at St. Audrie's Bay and Kuhjoch with each other. Instead, it advocates that the sharp negative CIE at Kuhjoch, here referred to as the Marshi CIE, should correlate with an older CIE in the Westbury Formation at St. Audrie's Bay. Correlation with the radiometrically dated TJB successions in Peru and Nevada, further shows that the Marshi CIE most likely post-dates and/or is synchronous to the bulk of the hitherto dated CAMP basalts. The consequences of the new correlation is that the deposition of the Cotham Member (St. Audrie's Bay), the grey siltstone interval (Stenlille), and the Triletes beds (Rødby, Mariental, Schandelah and Mingolsheim) was synchronous to deposition of the Schattwald beds (Kuhjoch). All these units were deposited during a regressive event and synchronous to the maximum marine and terrestrial extinction phases. This also means that the intense multiple seismic activity recorded across Europe, within the extinction interval; occurred after the bulk of the HTQ CAMP volcanism. It also means that the "initial CIE" at St. Audrie's Bay instead correlates with the CIE at the FO of Psiloceras spelae (here named the Spelae CIE), and equivalent CIEs in the other records. The FO of P. spelae occurs within the upper part of the Spelae CIE, which probably means that the sharp negative peak in the "initial CIE" at St. Audrie's Bay post-dates the maximum phase of extinction and pre-dates the TJB. At this level the terrestrial ecosystem was already beginning to recover, while the marine ecosystem remained disturbed.

\section{Acknowledgments}

This study was funded by Geocenter Denmark grant 2013-6. Jette Halskov (GEUS) is gratefully acknowledged for help with the illustrations. SL, GP, PA, KD, and LHN publish with permission of the Geological Survey of Denmark and Greenland. The authors are grateful to the editors David Bond and Thomas Algeo, as well as Andrea Marzoli and an anonymous reviewer for their helpful comments and suggestions.

\section{References}

Aarnes, I., Svensen, H., Connolly, J.A.D., Podladchikov, Y.Y., 2010. How contact metamorphism can trigger global climate changes: modeling gas generation around igneous sills in sedimentary basins. Geochim. Cosmochim. Acta 74, 7179-7195.

Alroy, J., 2010. Fair sampling of taxonomic richness and unbiased estimation of origination and extinction rates. In: Alroy, J., Hunt, G. (Eds.), Quantitative Methods in Paleobiology: The Paleontological Society Papers. 16, pp. 55-80.

Bertelsen, F., 1978. The Upper Triassic-Lower Jurassic Vinding and Gassum Formations of the Norwegian-Danish Basin. DGU Ser. B. 3 (26 pp).

Blackburn, T.J., Olsen, P.E., Bowring, S.A., McLean, N.M., Kent, D.V., Puffer, J., McHone, G., Rasbusry, E.T., Et-Touhami, M., 2013. Zircon U-Pb Geochronology links the end-Triassic extinction with the Central Atlantic Magmatic Province. Science 340:941-945. http://dx.doi.org/10.1126/science.1234204.

Blakey, R., 2014. Library of Paleogeography. Colorado Plateau Geosystems, Inc. (http:// cpgeosystems.com/paleomaps.html, accessed January 2015).

Bloos, G., 1999a. Aspekte der Wende Trias/Jura. In: Hauschke, R., Wilde, V. (Eds.), Trias: Eine ganz andere Welt. Pfeil., Munich, Germany, pp. 43-68.

Bloos, G., 1999b. Neophyllites (Ammonoidea, Psiloceratidae) in the earliest Jurassic of South Germany. Neues Jb. Geol. Paläontol. Abh. 211, 7-29.
Bloos, G., 2004. Psiloceratids of the earliest Jurassic in the North-West European and Mediterranean Provinces - remarks and new observations. Stuttg. Beitr. Naturkunde 347 (Serie B, 15 pp).

Bonis, N.R., Kürschner, W.M., 2012. Vegetation history, diversity patterns, and climate change across the Triassic/Jurassic boundary. Paleobiology 38, 240-264.

Bonis, N.R., Kürschner, W.M., Krystyn, L., 2009. A detailed palynological study of the Triassic-Jurassic transition in key sections of the Eiberg Basin (Northern Calcareous Alps, Austria). Rev. Palaeobot. Palynol. 156, 376-400.

Bonis, N.R., Ruhl, M., Kürschner, W.M., 2010. Milankovitch-scale palynological turnover across the Triassic-Jurassic transition at St. Audrie's Bay, SW UK. J. Geol. Soc. 167, 877-888.

Cirilli, S., Marzoli, A., Tanner, L., Bertrand, H., Buratti, N., Jourdan, F., Bellieni, G., Kontak, D. Renne, P.R., 2009. Latest Triassic onset of the Central Atlantic Magmatic Province (CAMP) volcanism in the Fundy Basin (Nova Scotia): new stratigraphic constraints. Earth Planet. Sci. Lett. 286, 514-525.

Clémence, M.E., Gardin, S., Bartolini, A., Paris, G., Beaumont, V., Guex, J., 2010. Benthoplanktonic evidence from the Austrian Alps for a decline in sea-surface carbonate production at the end of the Triassic. Swiss J. Geosci. 103, 293-315.

Dal Corso, J., Marzoli, A., Tateo, F., Jenkyns, H.C., Bertrand, H., Youbi, N., Mahmoudi, A. Font, E., Buratti, N., Cirilli, S., 2014. The dawn of CAMP volcanism and its bearing on the end-Triassic carbon cycle disruption. J. Geol. Soc. 171, 153-164.

Deenen, M.H.L., Ruhl, M., Bonis, N.R., Krijgsman, W., Kuerschner, W.M., Reitsma, M., van bergen, M.J., 2010. A new chronology for the end-Triassic mass extinction. Earth Planet. Sci. Lett. 291, 113-125.

Fowell, S.J., Olsen, P.E., 1993. Time calibration of Triassic-Jurassic microfloral turnover eastern North America. Tectonophysics 222, 361-369.

Götz, A.E., Ruckwied, K., Pálfy, J., Haas, J., 2009. Palynological evidence of synchronous changes within the terrestrial and marine realm at the Triassic/Jurassic boundary (Csóvar section, Hungary). Rev. Palaeobot. Palynol. 156, 401-409.

Guex, J., 1980. Remarques préliminares sur la distribution stratigraphique des ammonites hettangiennes du New York Canyon (Gabbs Valley Range, Nevada). Bull. Soc. Vaud. Sci. Nat. 75, 127-140

Guex, J., 1995. Ammonites hettangiennes de la Gabbs Valley Range (Nevada, USA). Mem. Geol. (Lausanne) 27 (131 pp).

Guex, J., Bartolini, A., Atudorei, V., Taylor, D., 2004. High-resolution ammonite and carbon isotope stratigraphy across the Triassic-Jurassic boundary at New York Canyon (Nevada). Earth Planet. Sci. Lett. 225, 29-41.

Guex, J., Bartolini, A., Taylor, D., Ayudorei, V., Thelin, P., Bruchez, S., Tanner, L., Lucas, S. 2009. Comment on: "the organic carbon isotopic and paleontological record across the Triassic-Jurassic boundary at the candidate GSSP section at Ferguson Hill, Muller Canyon, Nevada, USA." by Ward et al. (2007). Palaeogeogr. Palaeoclimatol. Palaeoecol. 273, 200-204

Hallam, A., 1981. The end-Triassic bivalve extinction event. Palaeogeogr. Palaeoclimatol. Palaeoecol. 35, 58-73.

Hallam, A., 1991. Reply to discussion on correlation of the Triassic-Jurassic boundary in England and Austria. J. Geol. Soc. Lond. 148, 421.

Hallam, A., Wignall, P.B., 1999. Mass extinctions and sea-level changes. Earth Sci. Rev. 48, 217-250.

Hallam, A., Wignall, P.B., 2004. Discussion on sea-level change and facies development across potential Triassic-Jurassic boundary horizons, SW Britain. J. Geol. Soc. Lond. 161, 1053-1056.

Hamberg, L., Nielsen, L.H., 2000. Shingled, sharp-based shoreface sandstones: depositional response to stepwise forced regression in a shallow basin, Upper Triassic Gassum Formation, Denmark. In: Hunt, D., Gawthorpe, R.L. (Eds.), Sedimentary Responses to Forced Regressions. Geol. Soc. Spec. Publ. 172, pp. 69-89.

Hansen, K.H., 2013. Vegetational Changes at the Triassic-Jurassic boundary - A Palynological Analysis of the Rødby-1 Well, Southern Denmark. (Master's Thesis). Department of Geosciences and Natural Resource Management, Faculty of Science, University of Copenhagen, pp. 1-72.

Hautmann, M., 2004. Effect of end-Triassic $\mathrm{CO}_{2}$ maximum on carbonate sedimentation and marine mass extinction. Facies 50, 257-261.

Hesselbo, S.P., Robinson, S.A., Surlyk, F., Piasecki, S., 2002. Terrestrial and marine extinction at the Triassic-Jurassic boundary synchronized with major carbon-cycle perturbations: a link to initiation of massive volcanism? Geology 30, 251-254.

Hesselbo, S.P., Robinson, S.A., Surlyk, F., 2004. Sea-level changes and facies development across potential Triassic-Jurassic boundary horizons, SW Britain. J. Geol. Soc. Lond. 161, 365-379.

Heunisch, C., Luppold, F.W., Reinhardt, L., Röhling, H.-G., 2010. Palynofazies, Bio- und Lithostratigraphie im Grenzbereich Trias/Jura in der Bohrung Mariental 1 (Lappwaldmulde, Ostniedersachsen). Z. Dtsch. Ges. Geowiss. 161, 51-98.

Hillebrandt, A.V., 1994. The Triassic/Jurassic boundary and Hettangian biostratigraphy in the area of the Utcubamba Valley (Northern Peru). Geobios 17, 297-307.

Hillebrandt, A.V., 1997. Proposal of the Utcubamba valley sections in Northern Peru. International Subcommission on Jurassic Stratigraphy. Newsletter. 24, pp. 21-25.

Hillebrandt, A.V., 2000a. Die ammoniten-Fauna des südamerikanischen Hettangium (basaler Jura), Teil I. Palaeontogr. A 257, 85-189.

Hillebrandt, A.V., 2000b. Die ammonite-fauna des südamerikanischen Hettangium (basaler Jura), Teil III. Palaeontogr. A 258, 65-116.

Hillebrandt, A.V., Kment, K., 2015. Psiloceratid ammonites from the Lower Hettangian of the Karwendel Mountains (Northern Calcareous Alps, Austria) and their biostratigraphic significance. N. Jb. Geol. Paläont. (Abh.) 277/3, 275-306.

Hillebrandt, A.V., Krystyn, L., 2009. On the oldest Jurassic ammonites of Europe (Northern Calcareous Alps, Austria) and their global significance. Neues Jb. Geol. Paläontol. Abh. 253, 163-195.

Hillebrandt, A.V., Kürschner, W.M., Krystyn, L., 2007. A candidate GSSP for the base of the Jurassic in the Northern Calcareous Alps (Kuhjoch section, Karwendel Mountains, Tyrol, Austria). In: Bown, P., Morton, N., Lees, J. (Eds.), International Subcommission on Jurassic Stratigraphy ISJS Newsletter. 34, pp. 2-20. 
Hillebrandt, A.V., Krystyn, L., Kürschner, W.M., Bonis, N.R., Ruhl, M., Richoz, S., Schobben M.A.N., Urlichs, M., Bown, P.R., Kment, K., McRoberts, C.A., Simms, M., Tomãsových, A 2013. The Global Stratotype Sections and Point (GSSP) for the Base of the Jurassic System at Kuhjoch (Karwendel Mountains, Northern Calcareous Alps, Tyrol, Austria). Episodes. 36 pp. 162-198.

Hounslow, M.W., Posen, P.E., Warrington, G., 2004. Magnetostratigraphy and biostratigraphy of the Upper Triassic and lowermost Jurassic succession, St. Audrie's Bay, UK. Palaeogeogr. Palaeoclimatol. Palaeoecol. 213, 331-358.

Ibarra, Y., Corsetti, F.A., Greene, S.E., Bottjer, D.J., 2016. A microbial carbonate response in synchrony with the end-Triassic mass extinction across the SW UK. Sci. Rep. 6 (19808), 1-8.

Jones, M.T., Jerram, D.A., Svensen, H.H., Grove, C., 2016. The effects of large igneous provinces on the global carbon and sulphur cycles. Palaeogeogr. Palaeoclimatol. Palaeoecol. 441, 4-21.

Korte, C., Hesselbo, S.P., Jenkyns, H.C., Rickaby, R.E., Spötl, C., 2009. Palaeoenvironmenta significance of carbon- and oxygen isotope stratigraphy of marine Triassic-Jurassic boundary sections in SW Britain. J. Geol. Soc. Lond. 166, 431-445.

Kürschner, W.M., Bonis, N.R., Krystyn, L., 2007. Carbon-isotope stratigraphy and palynostratigraphy of the Triassic-Jurassic transition in the Tiefengraben section Northern Calcareous Alps (Austria). Palaeogeogr. Palaeoclimatol. Palaeoecol. 244 257-280.

Lindström, S. 2016. Palynofloral patterns of terrestrial ecosystem change during the endTriassic event - a review. Geol. Mag. 153, 223-251.

Lindström, S., van de Schootbrugge, B., Dybkjær, K., Pedersen, G.K., Fiebig, J., Nielsen, L.H. Richoz, S., 2012. No causal link between terrestrial ecosystem change and methane release during the end-Triassic mass-extinction. Geology 40, 531-534.

Lindström, S., Pedersen, G.K., van de Schootbrugge, B., Hansen, K.H., Kuhlmann, N., Thein, J., Johansson, L., Petersen, H.I., Alwmark, C., Dybkjær, K., Weibel, R., Erlström, M. Nielsen, L.H., Oschmann, W., Tegner, C., 2015. Intense and widespread seismicity during the end-Triassic mass extinction due to emplacement of a large igneous province. Geology 43, 387-390.

Lund, J.J., 1977. Rhaetic to Lower Liassic palynology of the onshore south-eastern North Sea Basin. Dan. Geol. Unders. II (109), 1-129 (Række).

Mander, L., Twitchett, R.J., Benton, M.J., 2008. Palaeoecology of the Late Triassic extinction event in the SW UK. J. Geol. Soc., London 165, 319-332.

Mander, L., Kürschner, W.M., McElwain, J.C., 2013. Palynostratigraphy and vegetation history of the Triassic-Jurassic transition in East Greenland. J. Geol. Soc. 170, 37-46.

Marzoli, A., Bertrand, H., Knight, K.B., Cirilli, S., Vérati, C., Nomade, S., Martini, R., Youbi, N. Allenbach, K., Neuwerth, R., Buratti, N., Rapaille, C., Zaninetti, L., Bellieni, G., Renne, P.L., 2004. Synchrony of the Central Atlantic magmatic province and the Triassic-Jurassic boundary climatic and biotic crisis. Geology 32, 973-976.

Marzoli, A., Bertrand, H., Knight, K., Cirilli, S., Nomade, S., Renne, P., Vérati, C., Youbi, N., Martini, R., Bellieni, G., 2008. Comments on "synchrony between the Central Atlantic magmatic province and the Triassic-Jurassic mass-extinction event? By Whiteside et al. (2007)". Palaeogeogr. Palaeoclimatol. Palaeoecol. 262, 189-193.

Marzoli, A., Jourdan, F., Puffer, J.H., Cuppone, T., Tanner, L.H., Weems, R.E., Bertrand, H., Cirilli, S., Bellieni, G., De Min, A., 2011. Timing and duration of the Central Atlantic magmatic province in the Newark and Culpeper basins, eastern U.S.A. Lithos 122, 175-188.

McElwain, J.C., Beerling, D.J., Woodward, F.I., 1999. Fossil plants and global warming at the Triassic-Jurassic boundary. Science 285, 1386-1390.

McElwain, J.C., Popa, M.E., Hesselbo, S.P., Haworth, M., Surlyk, F., 2007. Macroecologica responses of terrestrial vegetation to climatic and atmospheric change across the Triassic/Jurassic boundary in East Greenland. Paleobiology 33, 547-573.

McGhee, G.R., Sheehan, P.M., Bottjer, D.J., Droser, M.L., 2004. Ecological ranking of Phanerozoic biodiversity crises: ecological and taxonomic severities are decoupled. Palaeogeogr. Palaeoclimatol. Palaeoecol. 211, 289-297.

McGhee, G.R., Clapham, M.E., Sheehan, P.M., Bottjer, D.J., Droser, M.L., 2013. A new ecological-severity ranking of major Phanerozoic biodiversity crises. Palaeogeogr. Palaeoclimatol. Palaeoecol. 370, 260-270.

McRoberts, C.A., Krystyn, L., Hautmann, M., 2012. Macrofaunal response to the end-Triassic mass extinction in the west-Tethyan Kössen Basin, Austria. Palaios 27, 607-616.

Mette, W., Elsler, A., Korte, C., 2012. Palaeoenvironmental changes in the Late Triassic (Rhaetian) of the Northern Calcareous Alps: clues from stable isotopes and microfossils. Palaeogeogr. Palaeoclimatol. Palaeoecol. 350-352, 62-72.

Michelsen, O., Nielsen, L.H., 1991. Well records on the Phanerozoic stratigraphy in the Fennoscandian Border Zone, Denmark. Hans-1, Sæby-1, and Terne-1 wells. Dan. Geol. Unders. Serie A 29 (37 pp).

Morton, N., 2012. Inauguration of the GSSP for the Jurassic System. Episodes 35, 328-332.

Nielsen, L.H., 2003. Late Triassic - Jurassic development of the Danish Basin and the Fennoscandian Border Zone, southern Scandinavia. Geol. Surv. Den. Greenl. Bull. 1 459-526

Nielsen, L.H., Japsen, P., 1991. Deep wells in Denmark 1935-1990, lithostratigraphic subdivision. Geol. Surv. Den., Ser. A 31 (180 pp)

Nørvang, A., 1957. The foraminifera of the Lias series in Jutland, Denmark. Medd. Dansk. Geol. Foren. 13, 275-414

Olsen, P.E., Kent, D.V., Sues, H.-D., Koeberl, C., Huber, H., Montanari, A., Rainforth, E.C., Fowell, S.J., Szajna, M.J., Hartline, B.W., 2002. Ascent of dinosaurs linked to an iridium anomaly at the Triassic-Jurassic boundary. Science 296, 1305-1307.

Page, K.N., 2003. The Lower Jurassic of Europe: its subdivision and correlation. Geol. Surv. Den. Greenl. Bull. 1, 23-59.

Pálfy, J., Zajzon, N., 2012. Environmental changes across the Triassic-Jurassic boundary and coeval volcanism inferred from elemental geochemistry and mineralogy in the Kendlbachgraben section (Northern Calcareous Alps, Austria). Earth Planet. Sci. Lett. 335-336, 121-134

Pedersen, G.K. 1985. Thin, fine-grained storm layers in a muddy shelf sequence: an example from the Lower Jurassic in the Stenlille 1 well. J. Geol. Soc. Lond. 142, 357-374.
Poulsen, N.E., 1996. Dinoflagellate cysts from marine Jurassic deposits of Denmark and Poland. AASP Contribution Series 31 (227 pp)

Quan, T.M., van de Schootbrugge, B., Field, M.P., Rosenthal, Y., 2008. Nitrogen isotope and trace metal analyses from the Mingolsheim core (Germany): evidence for redox variations across the Triassic-Jurassic boundary. Glob. Biogeochem. Cycles 22 (GB2014).

Raup, D.M., Sepkoski, J.J., 1982. Mass extinction in the marine fossil record. Science 215, $1501-1503$.

Richoz, S., van de Schootbrugge, B., Pross, J., Püttmann, W., Quan, T., Lindström, S., Heunisch, C., Fiebig, J., Maquil, R., Schouten, S., Hauzenberger, C.A., Wignall, P.B., 2012. Hydrogen sulphide poisoning of shallow seas following the end-Triassic extinction. Nat. Geosci. 5, 662-667.

Ruhl, M., Kürschner, W.M., 2011. Multiple phases of carbon cycle disturbance from large igneous province formation at the Triassic-Jurassic transition. Geology 39, 431-434.

Ruhl, M., Kürschner, W.M., Krystyn, L., 2009. Triassic-Jurassic organic carbon isotope stratigraphy of key sections in the western Tethys realm (Austria). Earth Planet. Sci. Lett. 281, 169-187.

Ruhl, M., Veld, H., Kürschner, W.M., 2010a. Sedimentary organic matter characterization of the Triassic-Jurassic boundary GSSP at Kuhjoch (Austria). Earth Planet. Sci. Lett. $292,17-26$

Ruhl, M., Deenen, M.H.L., Abels, H.A., Bonis, N.R., Krijgsman, W., Kürschner, W.M., 2010b. Astronomical constraints on the duration of the early Jurassic Hettangian stage and recovery rates following the end-Triassic mass extinction (St Audrie's Bay, East Quantoxhead, UK). Earth Planet. Sci. Lett. 295, 262-276.

Ruhl, M., Bonis, N.R., Reichart, G.-J., Sinninghe Damsté, J., Kürschner, W.M., 2011. Atmospheric carbon injection linked to end-Triassic mass extinction. Science 333, 430-434.

Schaltegger, U., Guex, J., Bartolini, A., Schoene, B., Ovtcharova, M., 2008. Precise U-Pb age constraints for end-Triassic mass extinction, its correlation to volcanism and Hettangian post-extinction recovery. Earth Planet. Sci. Lett. 267, 266-275.

Schoene, B., Guex, J., Bartolini, A., Schaltegger, U., Blackburn, T.J., 2010. Correlating the end-Triassic mass extinction and flood basalt volcanism at the $100 \mathrm{ka} \mathrm{level.} \mathrm{Geology}$ 38, 387-390

Sepkoski, J.J., 1996. Patterns of Phanerozoic extinction: a perspective from global data bases. In: Walliser, O.H. (Ed.), Global Events and Event Stratigraphy. Springer-Verlag, Berlin, pp. 35-51.

Simms, M.J., 2003. Uniquely extensive seismites from the latest Triassic of the United Kingdom: evidence for bolide impact? Geology 31, 557-560.

Simms, M.J., 2007. Uniquely extensive soft-sediment deformation in the Rhaetian of the UK: evidence for earthquake or impact? Palaeogeogr. Palaeoclimatol. Palaeoecol. 244, 407-423.

Sorgenfrei, T., Buch, A., 1964. Deep tests in Denmark. Dan. Geol. Unders. III 36, 1-146 (Række)

Stanley, S.M., 2007. An analysis of the history of marine animal diversity. Paleobiology Memoirs 4, 1-55.

Steinthorsdottir, M., Jeram, A.J., McElwain, J.C., 2011. Extremely elevated $\mathrm{CO}_{2}$ concentrations at the Triassic/Jurassic boundary. Palaeogeogr. Palaeoclimatol. Palaeoecol. 308, 418-432.

Tanner, L.H., Kyte, F.T., Richoz, S., Krystyn, L., 2016. Distribution of iridium and associated geochemistry across the Triassic-Jurassic boundary in sections at Kuhjoch and Kendlbach, Northern Calcareous Alps, Austria. Palaeogeogr. Palaeoclimatol. Palaeoecol. 449, 13-26.

Vajda, V., Raine, J.I., Hollis, C.J., 2001. Indication of global deforestation at the CretaceousTertiary boundary by New Zealand fern spike. Science 294, 1700-1702.

van de Schootbrugge, B., Tremolada, F., Rosenthal, Y., Bailey, T.R., Feist-Burkhardt, S., Brinkhuis, H., Pross, J., Kent, D.V., Falkowski, P.G., 2007. End-Triassic calcification crisis and blooms of organic-walled "disaster species". Palaeogeogr. Palaeoclimatol. Palaeoecol. 244, 126-141.

van de Schootbrugge, B., Payne, J.L., Tomasovych, A., Pross, J., Fiebig, J., Benbrahim, M., Föllmi, K.R., Quan, T.M., 2008. Carbon cycle perturbation and stabilization in the wake of the Triassic-Jurassic boundary mass extinction event. Geochem. Geophys. Geosyst 9, Q04028.

van de Schootbrugge, B., Quan, T.M., Lindström, S., Püttmann, W., Heunisch, C., Pross, J., Fiebig J., Petschick, R., Röhling, H.-G., Richoz, S., Rosenthal, Y., Falkowski, P.G. 2009. Floral changes across the Triassic/Jurassic boundary linked to flood basalt volcanism. Nat. Geosci. 2, 589-594.

Van Veen, P.M., 1995. Time calibration of Triassic/Jurassic microfloral turnover, eastern North America-comment. Tectonophysics 245, 93-95.

Ward, P.D., Haggart, J.W., Carter, E.S., Wilbur, D., Tipper, H.W., Evans, T., 2001. Sudden productivity collapse associated with the Triassic-Jurassic boundary mass-extinction. Science 292, 1148-1151.

Ward, P.D., Garrison, G.H., Haggart, J.W., Kring, D.A., Beattie, M.J., 2004. Isotopic evidence bearing on Late Triassic extinction events, queen Charlotte Islands, British Columbia, and implications for the duration and cause of the Triassic/Jurassic mass extinction. Earth Planet. Sci. Lett. 224, 589-600.

Ward, P.D., Garrison, G.H., Williford, K.H., Kring, D., Goodwin, D., Beattie, M., McRoberts, C., 2007. The organic carbon isotopic and paleontological record across the TriassicJurassic boundary at the candidate GSSP section at Ferguson Hill, Muller Canyon, Nevada, USA. Palaeogeogr. Palaeoclimatol. Palaeoecol. 244, 279-287.

Whiteside, J.H., Olsen, P.G., Kent, D.V., Fowell, S.J., Et-Touhami, M., 2007. Synchrony between the Central Atlantic magmatic province and the Triassic-Jurassic mass-extinction event? Palaeogeogr. Palaeoclimatol. Palaeoecol. 244, 345-367.

Whiteside, J.H., Olsen, P.E., Kent, D.V., Fowell, S.J., Et-Touhami, M., 2008. Synchrony between the Central Atlantic magmatic province and the Triassic-Jurassic mass-extinction event? Reply to comment of Marzoli et al., 2008. Palaeogeogr. Palaeoclimatol. Palaeoecol. 262, 194-198.

Whiteside, J.H., Olsen, P.E., Eglinton, T., Brookfield, M.E., Sambrotto, R.N., 2010. Compound-specific carbon isotopes from Earth's largest flood basalt eruptions directly linked to the end-Triassic mass extinction. Proc. Natl. Acad. Sci. 107, 6721-6725. 
Wignall, P.B., Bond, D.P.G., 2008. The end-Triassic and Early Jurassic mass extinction records in the British Isles. Proc. Geol. Assoc. 119, 73-84.

Wignall, P.B., van de Schootbrugge, B., 2016. Middle Phanerozoic mass extinctions and a tribute to the work of Professor Tony Hallam. Geol. Mag. 153, 195-200.

Williford, K.H., Ward, P.D., Garrison, G.H., Buick, R., 2007. An extended organic carbon-isotope record across the Triassic-Jurassic boundary in the Queen Charlotte Islands, British Columbia, Canada. Palaeogeogr. Palaeoclimatol. Palaeoecol. 244, 290-296.
Wotzlaw, J.-F., Guex, J., Bartolini, A., Gallet, Y., Krystyn, L., McRoberts, C.A., Taylor, D. Schoene, B., Schaltegger, U., 2014. Towards accurate numerical calibration of the late Triassic: high-precision U-Pb geochronology constraints on the duration of the Rhaetian. Geology 42, 571-574.

Zajzon, N., Kristály, F., Pálfy, J., Németh, T., 2012. Detailed clay mineralogy of the TriassicJurassic boundary section at Kendlbachgraben (Northern Calcareous Alps, Austria). Clay Miner. 47, 177-189. 